\title{
DOE/PC/91008--23-Pt.8 \\ Overview of the Structural \\ Geology and Tectonics of \\ the Central Basin Platform, \\ Delaware Basin, and \\ Midland Basin, West Texas \\ and New Mexico
}

T. Hoak ${ }^{a}$, K. Sundbergb, and P. Ortolevac

a Kestrel Geoscience, LLC

9683 West Chatfield Avenue, Unit D

Littleton, Colorado 80128

b Phillips Petroleum Company

252 Geoscience Building

Bartlesville, Oklahoma 74003

c Laboratory for Computational Geodynamics

Department of Chemistry

Indiana University

Bloomington, Indiana 47405 


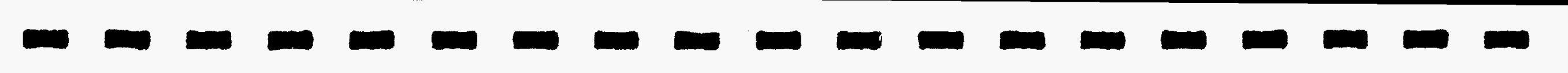




\section{DISCLAIMER}

Portions of this document may be illegible in electronic image products. Images are produced from the best available original document. 


\section{Table of Contents}

Introduction.

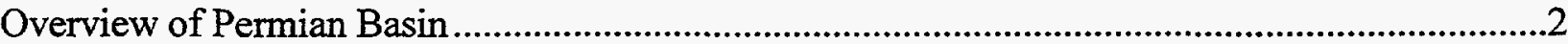

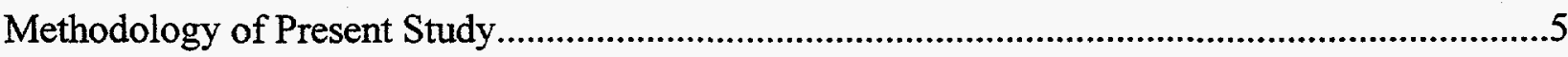

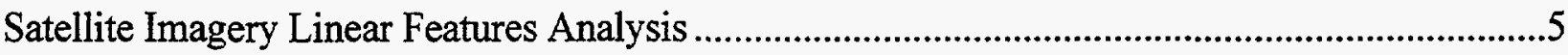

Comparison to Maps Based on Earlier Aerial Photo Interpretation .........................................18

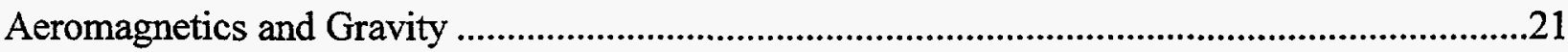

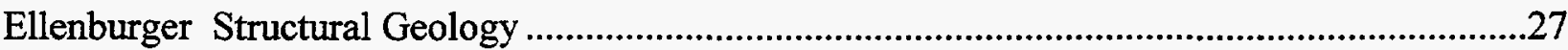

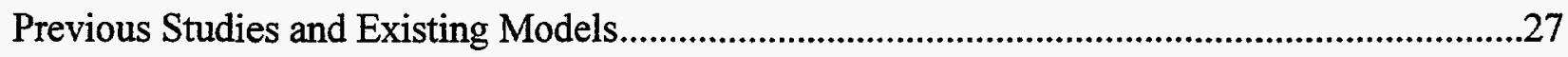

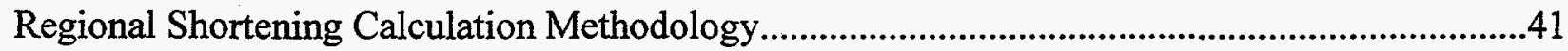

Tectonic Development and Stress Regimes Throughout Basin Evolution.................................45

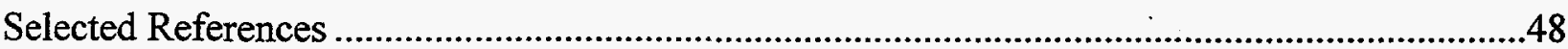

\section{DISCLAIMER}

This report was prepared as an account of work sponsored by an agency of the United States Government. Neither the United States Government nor any agency thereof, nor any of their empleyees, makes any warranty, express or implied, or assumes any legal liability or responsibility for the accuracy, completeness, or usefulness of any information, apparatus, product, or process disclosed, or represents that its use would not infringe privately owned rights. Reference herein to any specific commercial product, process, or service by trade name, trademark, manufacturer, or otherwise does not necessarily constitute or imply its endorsement, recommendation, or favoring by the United States Government or any agency thereof. The views and opinions of authors expressed herein do not necessarily state or reflect those of the United States Government or any agency thereof. 


\section{List of Figures:}

FIGURE 1: LOCATION MAP OF PERMLAN BASIN AND MODELING AREA. 3

FIGURE 2: SCHEMATIC MODEL OF BASEMENT CONTROL ON SURFACE LINEAR FEATURES .6

FIGURE 3: BOUNDARIES OF LANDSAT IMAGES USED FOR ANALYSIS

FIGURE 4: COMPOSITE IMAGE OF ALL INTERPRETED LINEAR FEATURES

FIGURE 5: ROSE DLAGRAMS OF INTERPRETED LINEAR FEATURES.

FIGURE 6: EFFECT OF FILTERING DATA FROM MESCA IMAGE TO REMOVE AEOLIAN (?) FEATURES. 12 FIGURE 7: ROSE DIAGRAMS COMPARING SUBSURFACE STRUCTURE AND SURFICLAL LINEARS 16

FIGURE 8: MAP OVERLAY OF SUBSURFACE STRUCTURE AND SURFICIAL LNEAR FEATURES. 17

FIGURE 9: COMPOSITE MAP OF PHOTOLINEAR AND SATELLITE RNTERPRETATIONS 19

FIGURE 10: ROSE DLAGRAMS COMPARING PHOTOLINEAR AND SATELLITE INTERPRETATIONS. 20

FIGURE 11: INTERPRETED CRUSTAL BLOCKS ON BOUGUER GRAVTTY BASE MAP 23 FIGURE 12: INTERPRETED CRUSTAL BLOCKS ON AEROMAGNETIC BASE MAP 24

FIGURE 13: CROSS-SECTIONS ALONG SOUTHWEST MARGIN OF CENTRAL BASIN PLATFORM...............25

FIGURE 14: CROSS-SECTIONS ALONG SOUTHWEST MARGIN OF CENTRAL BASIN PLATFORM................26

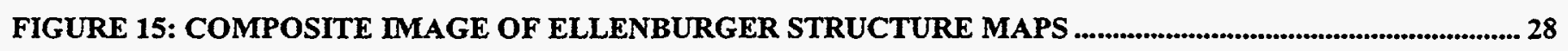

FIGURE 16: SCHEMATIC MODEL OF FAULT-BEND FOLDS (FROM SUPPE, 1979).............................................29

FIGURE 17: INTERPRETED CRUSTAL BLOCKS FROM GARDINER (1990)......................................................35

FIGURE 18: INTERPRETED CRUSTAL BLOCKS ON ELLENBURGER STRUCTURAL BASEMAP..................... 36

FIGURE 19A: CROSS-SECTIONS ALONG SOUTHWEST MARGIN OF CENTRAL BASIN PLATFORM ............. 37

FIGURE 19B: CROSS-SECTIONS ALONG SOUTHWEST MARGIN OF CENTRAL BASIN PLATFORM ............. 38

FIGURE 20: INTERPRETATION OF REGIONAL KINEMATICS (SHUMAKER, 1992) ............................................... 39

FIGURE 21: REGIONAL SHORTENING CALCULATIONS FROM YANG AND DOROBEK (1995) ......................42

FIGURE 22: INTERPRETATION OF REGIONAL KINEMATICS (YANG AND DOROBEK, 1995)........................43

FIGURE 23: METHODOLOGY FOR REGIONAL SHORTENING CALCULATION................................................ 4 


\section{APPENDIX B: Structural Geology and Tectonics}

\section{Introduction}

The structural geology and tectonics of the Permian Basin were investigated using an integrated approach incorporating satellite imagery, aeromagnetics, gravity, seismic, regional subsurface mapping and published literature. The two primary emphases were on; 1) delineating the temporal and spatial evolution of the regional stress state; and 2) calculating the amount of regional shortening or contraction. Secondary objectives included delineation of basement and shallower fault zones, identification of structural style, characterization of fractured zones, analysis of surficial linear features on satellite imagery and their correlation to deeper structures.

Gandu Unit, also known as Andector Field at the Ellenburger level and Goldsmith Field at Permian and younger reservoir horizons, is the primary area of interest and lies in the northern part of Ector County. The field trends northwest across the county line into Andrews County. The field (s) are located along an Ellenburger thrust anticline trap on the eastern margin of the Central Basin Platform (see Figure 1 for location).

\section{Overview of Permian Basin}

Before conducting detailed discussions about the geology of the Permian Basin, it is helpful to provide some geographic boundaries and review the primary geologic elements that compose the region. Figure 1 represents a location map that outlines the primary areas of interest in the Permian Basin. This map also outlines the location of the proposed modeling area.

The study area lies on the eastern margin of the Central Basin Platform and extends eastward into the adjacent Midland Basin (see outline of area on Figure 1). The Central Basin Platform is a NWtrending uplifted basement block that separates the Midland Basin (to the east) from the Delaware Basin (to the west). The Central Basin Platform (or CBP) was uplifted in mid-late Pennsylvanian time. Until that time, the two basins and the CBP were relatively low relief features within a shallow Paleozoic-age basin that has been called the Tobosa Basin. Following the development of the two individual basins by uplift of the CBP, the Tobosa Basin ceased to exist. The Central Basin Platform represents an uplifted zone of basement rock. As a result, drilling depths to deeper reservoir horizons (e.g. Ellenburger 


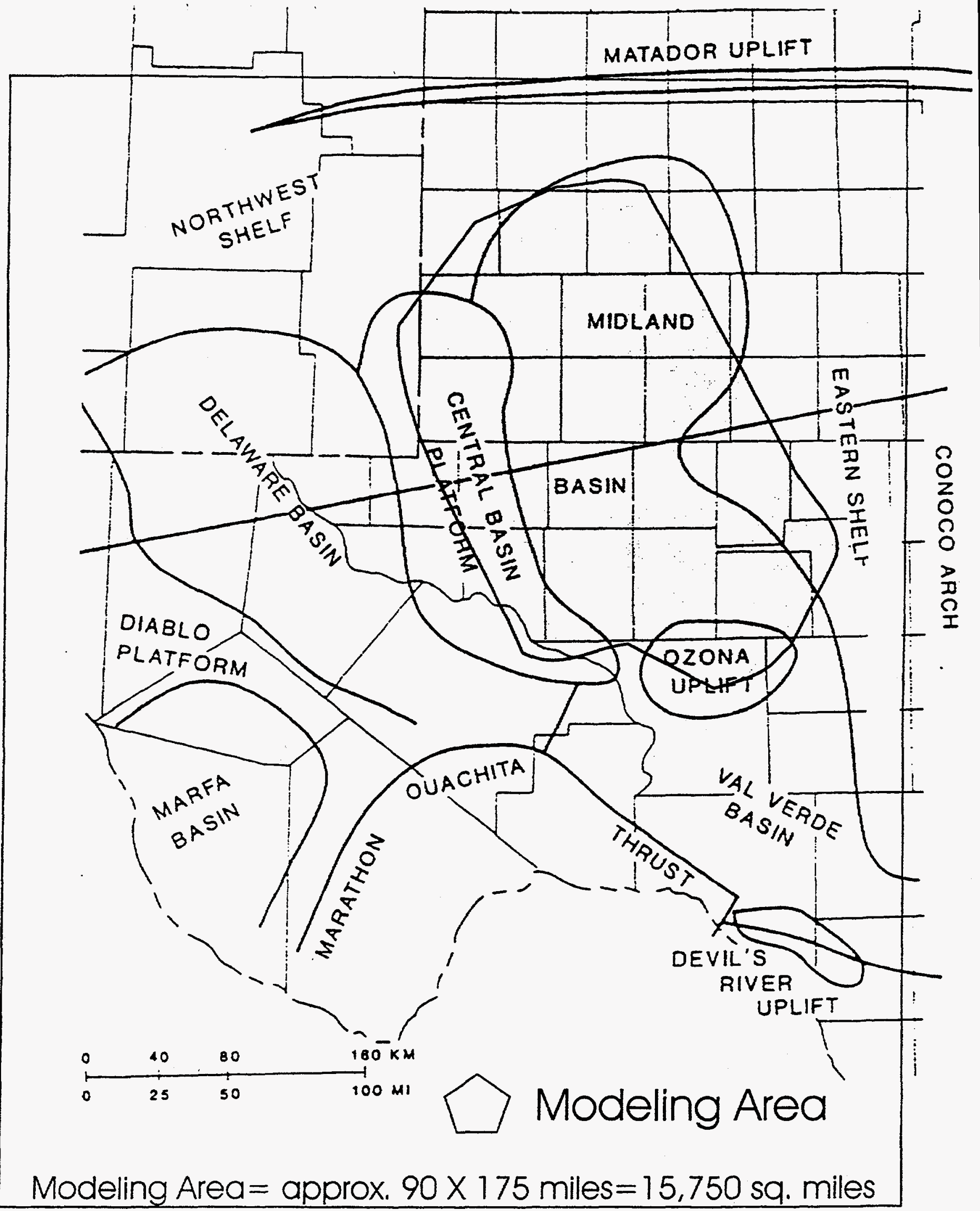

Figure 1. Location map of major structural elements and modeling area in the Permian Basin, West Texas (after Hanson et al., 1991) 
Formation) is much shallower. This shallow drilling greatly improves the economics of wells and fields along this structure.

In Wolfcampian time, the uplift of the CBP ceased, and a regional erosional unconformity developed that beveled off the top of the underlying structures. Above this unconformity, the carbonate reef and related proximal facies were deposited on the relatively flat erosional surface. A consequence of this erosional event and subsequent deposition is that deeper fold and thrust structures are capped by flat-lying carbonate reservoirs at shallower depths. These stratigraphic trap reservoirs, together with the deeper structural traps, represent a complex system of multiple pay zones that greatly increase the economic potential of drilling activity in this area.

The northern termination of the CBP is the Northwest Shelf. The Northwest Shelf represents a broad shelf extending northward to the Palo Duro Basin. This shelf, though only slightly faulted, extends from the Midland Basin to the broad depositional shelf that extends northward to the Matador Arch. The San Simon Syncline represents a narrow sag that separates the CBP from the shelf region. The southern termination of the CBP is the Val Verde Basin. The Val Verde Basin represents a foredeep basin of the Pennsylvanian and early Permian-age Marathon Fold-and-Thrust Belt. The Val Verde Basin is filled with over 15,0000 feet $(>5000 \mathrm{~m}$ ) of flysch and related clastic rocks derived from the advancing thrust sheets.

The Midland Basin represents the primary focus of this study. In cross-section perpendicular to the basin axis, its shape is slightly asymmetric and deepens to the west. The western boundary is delineated by the complex folds and faults that have formed along the eastern margin of the Central Basin Platform (including the Gandu Unit). The eastern basin boundary is somewhat indistinct and is designated the Eastern Shelf. The Eastern Shelf represents a gradual rise from the western, deepest part of the basin. As a result, the eastern boundary of the Midland Basin is somewhat arbitrary.

The Delaware Basin contrasts strongly with the Midland Basin. The Delaware Basin is significantly deeper, is more asymmetric and deepens to the east. Because of its greater burial depth and sediment influx, organic sediments in the Delaware Basin have experienced greater thermal maturity and much of the deeper hydrocarbon reserves have been converted to natural gas. The western margin of the Delaware Basin is bounded by the Salt Flat Graben, a Tertiary-age system related to the Basin-and-Range extensional tectonics. Finally, further to the west, lies the Diablo Platform, a paleogeographic high that has persisted since the Paleozoic. 


\section{Methodology of present study}

The structural geology and tectonics of the Permian Basin were investigated using an integrated approach incorporating satellite imagery, aeromagnetics, gravity, seismic, regional subsurface mapping and published studies from the literature. There are two primary fractured reservoirs of interest in the primary modeling area of the Gandu Unit. The deepest reservoir is the Ellenburger Formation and the second is the shallower Clearfork Formation. The Ellenburger, considered a classic fractured reservoir, was deformed by contractional (thrust) tectonics during the Pennsylvanian-age Ouachita Orogeny that caused the majority of regional deformation. The younger, Permian-age Clearfork Formation was not affected by this deformation and is not generally regarded as a fractured reservoir. However, detailed analysis of core from this formation demonstrates that significant vuggy porosity is present that is interconnected with microcracks. Given the low permeability of the Clearfork in the Gandu Unit, we believe that the microcracks and related vuggy porosity represent the critical pathways for fluid flow. Understanding the genesis of these fractures is a major objective for our modeling effort.

To assess the potential for basement and deeper structural control on the permeability and fracture trends in the Clearfork reservoir, we investigated the relationship between basement and Ellenburger structural trends, and surficial trends observed on satellite imagery. If a correlation exists between the different structural levels, this would indicate the likelihood that the intermediate Clearfork structural level possesses similar structural anisotropy trends. An illustration of these relationships is shown in Figure 2. To accomplish this comparison, a linear features analysis was conducted of three LANDSAT thematic mapper images that span an area from the western edge of the Delaware Basin (Delaware Mountains) northeastward across the Central Basin Platform to the approximate center of the Midland Basin. The along-strike variations were assessed along the length of the Central Basin Platform by examining the area to the northwest of the Gandu Unit.

\section{Satellite imagery linear features analysis}

Linear features represent segments of streams, arroyos, escarpments, ridges and cliffs. Additional linear features arise from spectral differences between rock/soil types, vegetation-types/density and soil moisture content. No obvious cultural features were interpreted, however, every interpreted feature was not compared to topographic maps in order to eliminate all known cultural sources such as ranch roads, seismic survey lines, oil field infrastructure, etc. The majority of linear features were compared with 


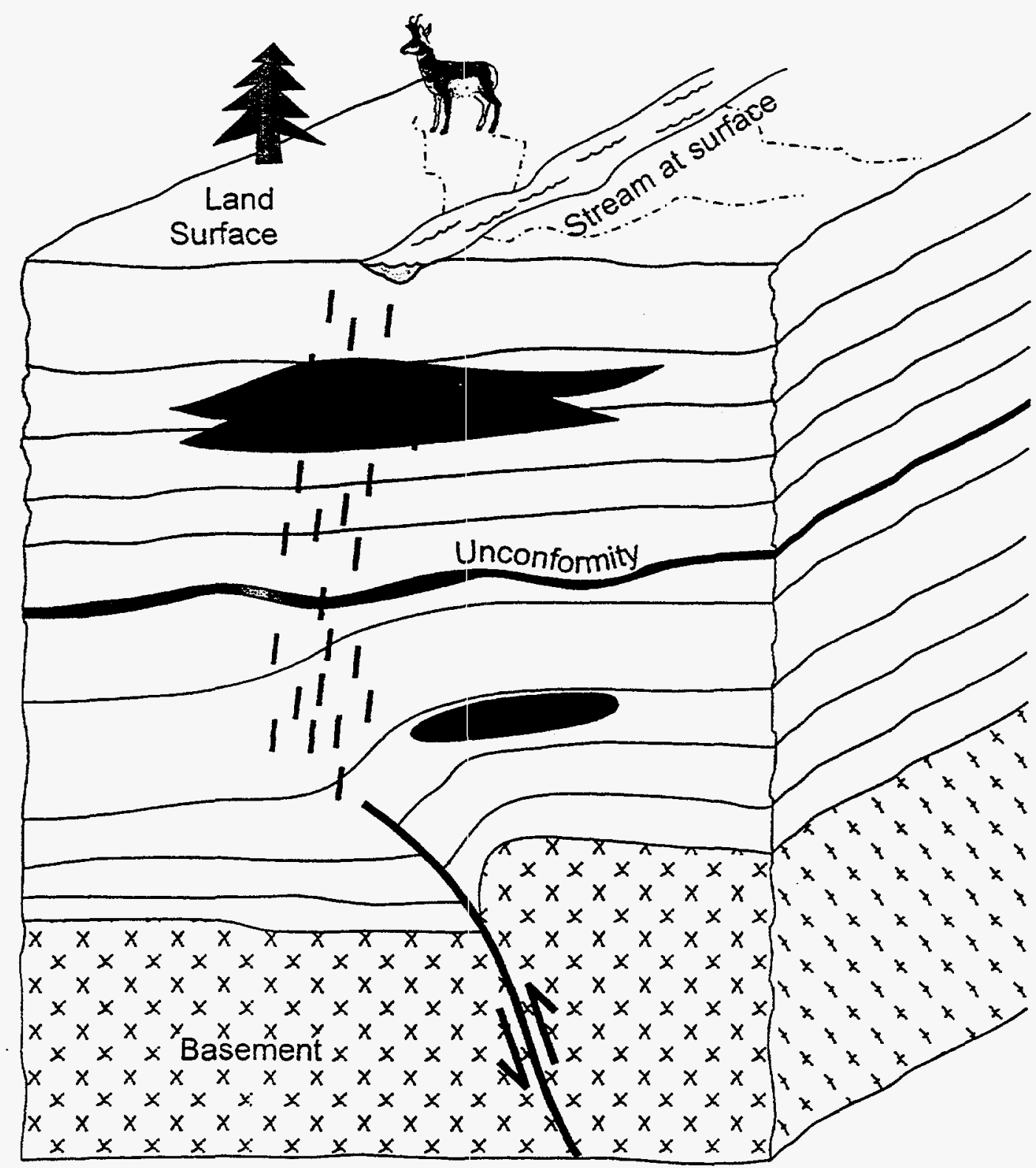

oil reservoir

Figure 2. Schematic diagram illustrating relationship between topographic surface, subsurface reservoirs and deeper basement level structures.

Basement related structural deformation will

propagate up through the stratigraphic section and be expressed on the surface as a subtle linear feature. 
published geologic maps. Interpreted features were not field inspected to determine the nature of the linear feature anomaly due to practical time constraints. Linears were also compared to published, fieldverified aerial photolinear studies for the area of Ector County.

LANDSAT and other satellite-based imagery provide an excellent opportunity to rapidly perform an analysis over a wide area. The large area covered by the image provides a regional perspective difficult to achieve using conventional aerial photography. Whereas the larger scale image of the aerial photos do reveal greater ground detail, their use over large areas requires large numbers of photos that often prevent regional features from being readily apparent. It should be emphasized, however, that more recent satellite imagery systems (e.g. 10 meter resolution monochromatic SPOT from France, and 3 meter resolution Soyuz-Karta KVR1000 satellite imagery from the former Soviet Union) have resolution very close to that of high-altitude aerial photography (approximately 1 meter resolution) with the flexibility to perform interactive processing of the image to maximize the information that can be obtained from the data. It is for this reason that satellite imagery is preferable to aerial photo interpretation although the cost of the latter is significantly less.

The three images were designated as Pecos, Midland and Mesca in reference to the dominant geographic element in each scene (see Figure 3 for boundaries of individual LANDSAT imagery scenes). The Pecos image is centered on the Pecos River and extends from the Delaware Mountains on the west across the Delaware Basin and Central Basin Platform into the Midland Basin. The Midland image is centered on the Midland-Odessa area and overlaps with the Pecos sheet. It covers the eastern margin of the Central Basin Platform and the western Midland Basin. The Mesca image is named for the Mescalero Ridge. It represents the northwestward continuation of the Central Basin Platform as observed in the other sheets and covers the eastern and western margins of the Central Basin Platform. Additional regional coverage was examined to confirm that these major linear feature trends are also present on these sheets. These additional images were not included in the present study because they extended significantly beyond the primary boundaries of the area of interest, and processing and interpretation for these areas was not included in the budget.

Linear features were interpreted on transparent overlays from the three images provided by Phillips Petroleum. These linears were digitized and put on a computer-based regional base map to compare the interpreted linear features with underlying structural trends at the Ellenburger level (discussed in more detail later). The composite image of all linear features (see Figure 4) shows a wide 
range of linear feature trends. Several regional lineaments have been previously interpreted for this area of Texas. Work by Bolden (1984) interpreted several major WNW-trending lineaments referred to as the Pecos Lineament and the Concho Lineament. These were interpreted as representing left-lateral wrench systems. Less prominent NE-trending linear zones were interpreted as the right lateral antithetic shear set. These two zones have been added to Figure 4. Note that the Pecos Lineament is composed of a series of parallel, shorter linear features. There are several areas along the Pecos River where small NEtrending linear features disrupt the continuity of the larger NW and WNW-trending linears. Although the significance of these linears is unknown, both the Pecos and Concho lineaments seem to have clear expression in the LANDSAT images interpreted during this study. Whether these lineaments represent regional wrench or strike-slip systems cannot be verified with the existing data.

Linear features from the three images were interpreted using strike-frequency diagrams (rose diagrams). These diagrams show the dominant linear feature orientations (azimuths) that are present in the data. Figure 5 shows the rose diagrams for the three domains. The Pecos region is the most instructive because of the diversity of fault trends that have been mapped on the surface (Geologic Atlas of Texas, Van Horn-El Paso Sheet, Barnes, 1983; Tectonic Map of Texas, Ewing et al., 1995). Faults in the Apache Mountains (to west of Delaware Basin) trend E/W to WNW and are crosscut by NNW and NW-trending faults that trend parallel to those exposed in the Delaware Mountains that form the Salt Flat Basin graben system. In the Delaware Mountains (also to west of Delaware Basin), NE-trending faults are also present although they appear subordinate to the larger displacements observed on the NNW and NW-trending sets. Many of these mapped faults occur along topographic depressions and drainages. Based on these observed relationships and the orientations observed in the Van Horn-El Paso Sheet, we have interpreted the linear feature trends mapped in the Pecos image to represent subsurface faults that do not appear at the surface. Instead, these subsurface faults create a preferred orientation for regional drainages and other linear anomalies. Given the dominant trends observed in the Pecos image, and the similarity of these linear feature trends to those mapped faults further west, it is reasonable to conclude that the linear features overlie subsurface fracture systems.

On the Midland image, we see less of the NE-trend and a larger number of WNW linears. In this area, a greater percentage of regional drainages lie parallel to this trend. In the Pecos image, we found significant numbers of N/S, NE, WNW and E/W-trending drainages. After we cross the Pecos River, however, we find that the NE and WNW trends become dominant. This difference in linear feature 


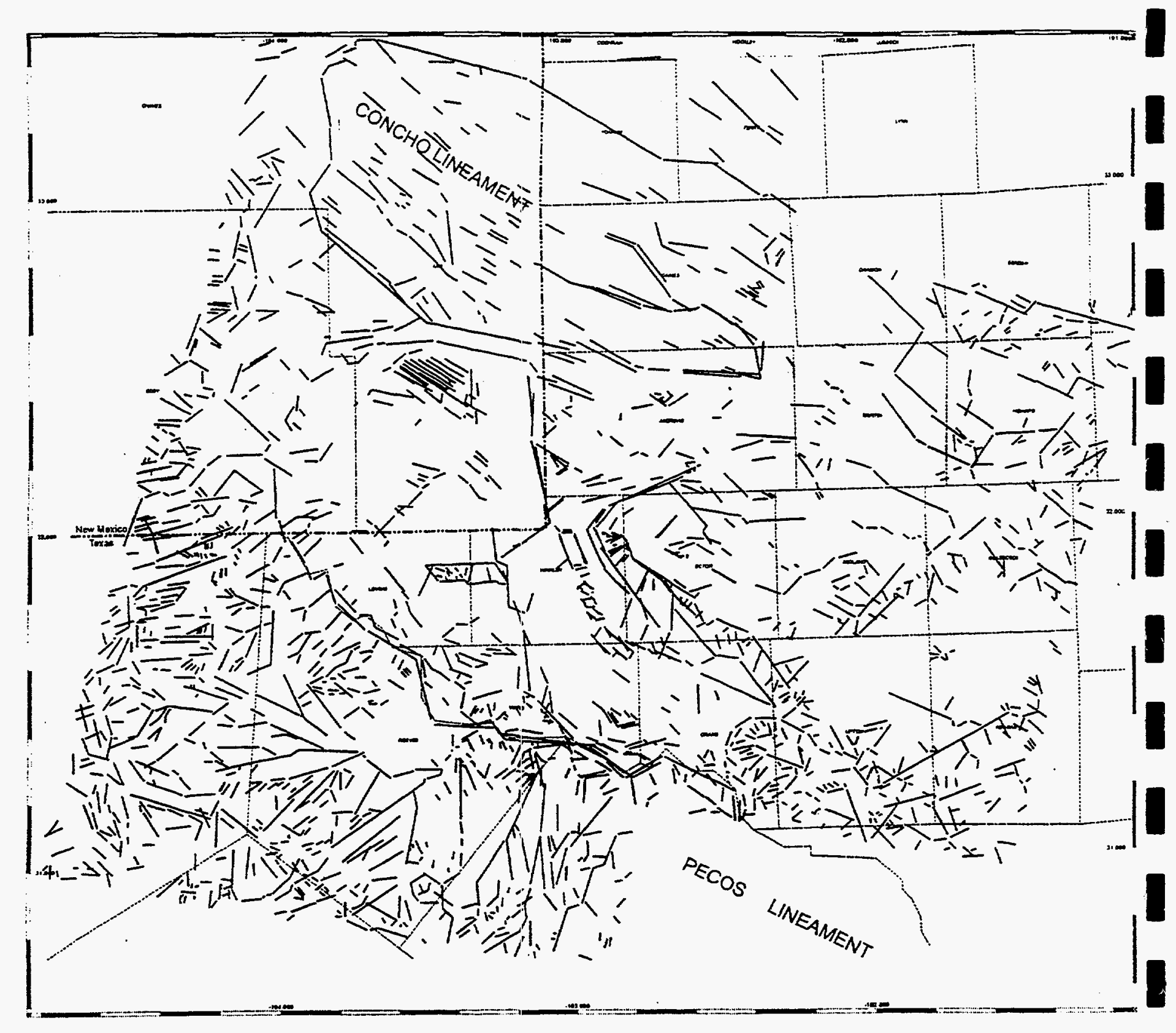

Figure 4: Composite Image of all interpreted linear Features Concho and Pecos regional lineaments from Bolden (1984) 


\section{Interpreted Linear Features: Rose Diagrams}

Pecos Region

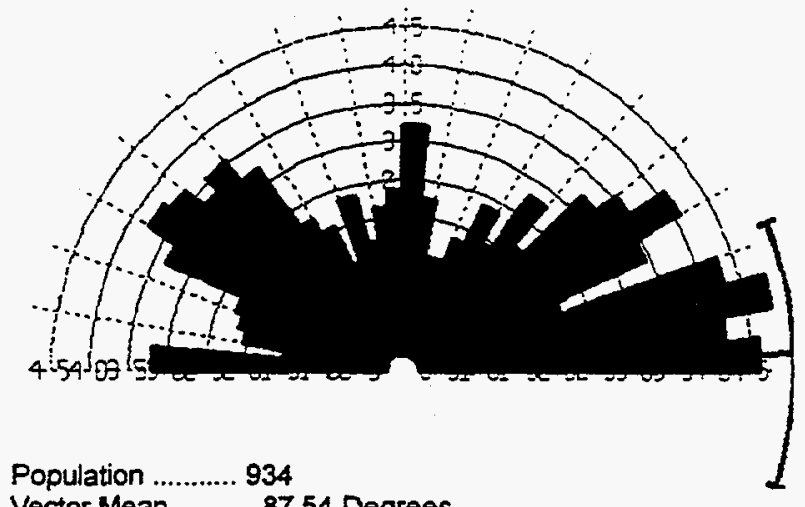

Vector Mean
Midland Region

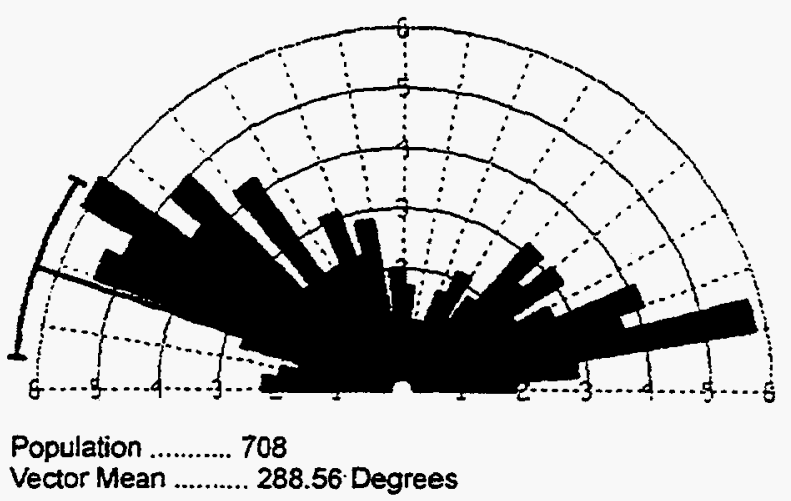

Mesca Region

(filtered data to remove aeolian (?) features possessing trends between $280-310^{\circ}$ )

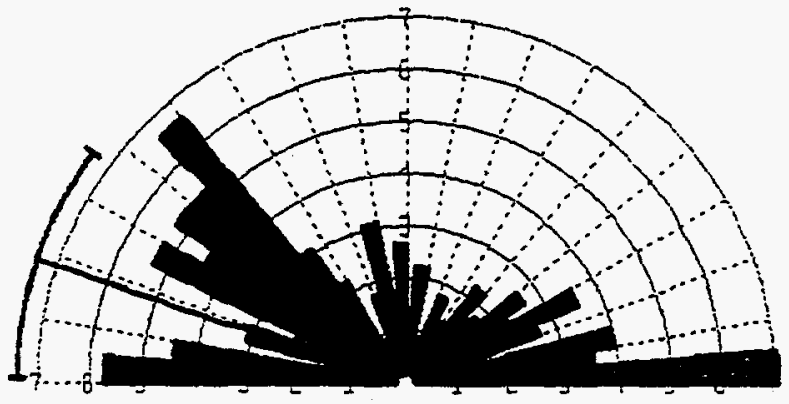

Population .......... 227

Vector Mean .......... 288.52 Degrees

Figure 5: Orientations of linear features for the LANDSAT images. See Figure 3 for scene boundaries. 


\section{Interpreted Linear Features: Rose Diagrams (filtered)}

\section{Mesca Region}

(all orientations, unfiltered)

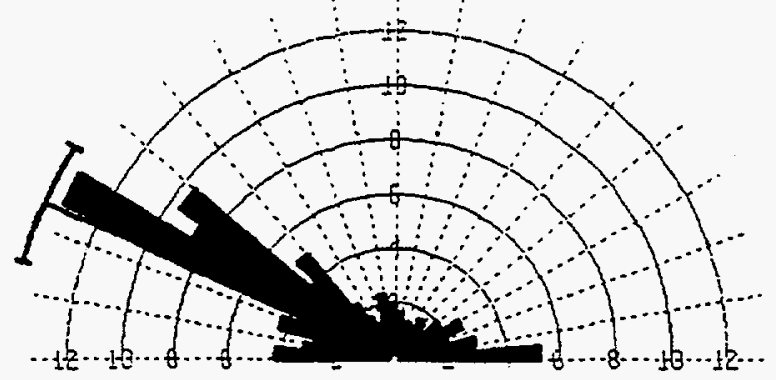

Population ........... 305

Vector Mean .......... 293.87 Degrees

\section{Mesca Region}

(filtered data to remove aeolian (?) features possessing trends between $290-300^{\circ}$ )

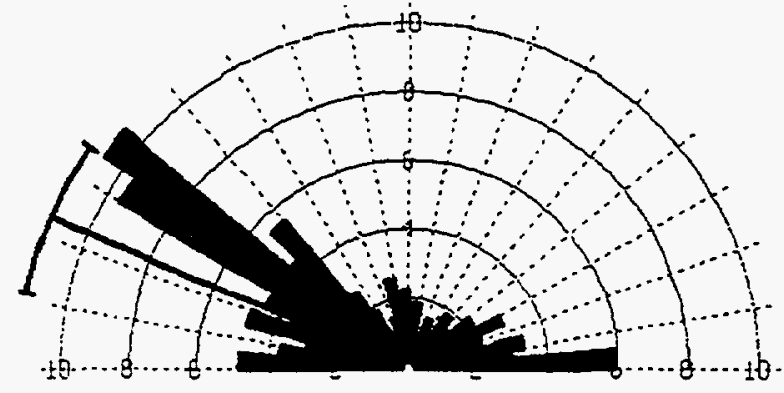

\section{Mesca Region}

(filtered data to remove aeolian (?) features possessing trends between $280-310^{\circ}$ )

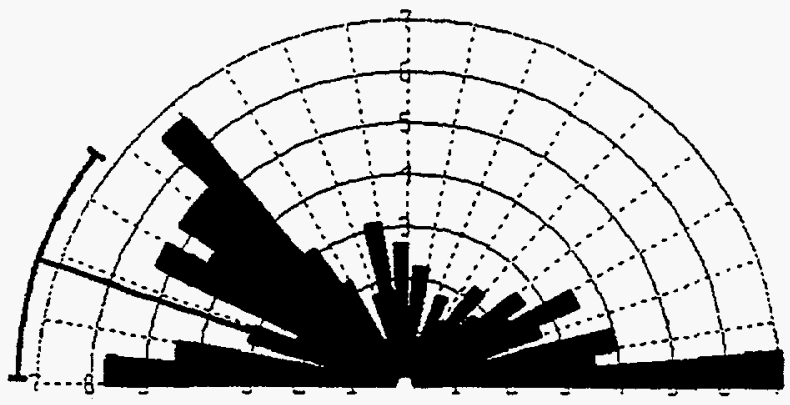

Population ........... 227

Vector Mean .......... 288.52 Degrees

\section{Mesca Region}

(filtered data to remove aeolian (?) features possessing trends between $300-310^{\circ}$ )

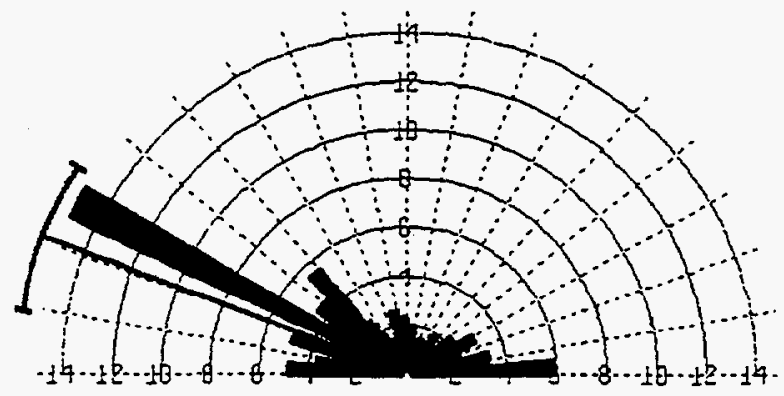

Population ........... 272

Vector Mean

290.7 Degrees

Figure 6: Effect on frequency diagrams created by filtering the Mesca image data set to remove the influence of pronounced aeolian (?) features possessing a NW trend. Upon removal of NW trend, rose diagram appears similar to those calculated from the Pecos and Midland images. 
orientation across the Pecos River probably reflects the influence of the major wrench system that has been interpreted to lie along the Pecos River trend (Bolden, 1984).

In the Mesca image, there is a dominance of WNW linear features. This trend is expressed by topographic drainages and differences in sediment composition infilling these topographic lows spots. According to the map legend (Geologic Atlas of Texas, Big Spring Sheet, Barnes, 1983), these sediments are aeolian deposits that have infilled topographic depressions. The rose diagram for the Mesca region has included these aeolian deposits because they infill these depressions. Given the aeolian nature of the sediments, it is likely that the WNW trend we observe is actually a reflection of the prevailing wind direction. We have also filtered the total linear features data set for this image area to remove the dominant WNW trend. The effect of these various filters is shown in Figure 6. When these linear feature azimuths $\left(280-300^{\circ}\right)$ are removed, the data set looks very similar to that for the Midland region with a greater percentage of E/W-trending feature similar to those in the Pecos image.

Based on the similarities and differences between the three data sets, it appears that the Pecos River is a major zone that separates the linear feature fabric of the Pecos region from that of the Mesca and Midland regions to the north. North of the river, there is a remarkable similarity in orientations. By analogy with the Van Horn area to the west and south of the primary area, it is likely that the various linear features represent incipient fault systems given the similarity observed between fault trends between that area and the interpreted linear features of the study area.

To assess basement and deep subsurface control on the linear feature trends, the location of the observed surficial linear features were compared against detailed subsurface structure maps at the Ordovician-age Ellenburger Formation level. A comparison of these faults and related fold axes against the surficial linear features is made in Figure 7. From these rose diagrams, we find that the subsurface faults possess a dominance of NNW and WNW trends with subordinate NNE trends. Although this is similar to the surficial linears, the NE-trend observed in the surface does not appear as prominent at depth. Given the variation in displacement along most of the deeper NW-trending regional faults, and the locally prominent subsurface presence (especially in the Andector-Gandu Unit) of NE-trending crossfaults, it is likely that the NE fault trend is present to permit differential regional displacement and subsidence along the NW fault trends. It is possible that the NE-trend results from preferential dissolution of shallow evaporites along faults that formed at shallower levels orthogonal to the deeper 
regional trends (Hills, 1984; 1985). Displacement along these orthogonal faults would be essential to insure strain compatibility and permit the observed differential displacements along the length of the NW-trending regional faults.

Visual inspection of an overlay map (Figure 8) between individual surficial linear features and subsurface structural trends, it is clear that there are significant areas where an excellent correspondence exists. Given the depth ( $>8000$ ' for most areas) of the subsurface structure, it should be expected that there will be some lateral offset of surficial linear features compared to the subsurface structural location. There are, however, several areas where there is less or little correlation between the individual subsurface structures and surficial linears. This apparent lack of correlation, however, is largely because subsurface maps do not show structures beneath all linears. In contrast, nearly all subsurface structures have linear features associated with them. This may be a function of subsurface data density in that areas off the Central Basin Platform that do not possess large numbers of deep penetrations. Additional regional mapping on deep subsurface horizons and comparison to surficial linears would be necessary to evaluate this hypothesis.

It was expected, based on results from other regions, that there would be a correlation between individual, large displacement subsurface faults and corresponding surficial linear trends. In Gaines and Andrews counties, there is an excellent correspondence between larger subsurface faults and surficial linear features. Only where the Concho Lineament crosses through the area are there a large number of oblique surficial linear feature trends that do not correlate to the subsurface. Further south, in Ector and Midland counties, there is also good correlation between larger subsurface faults and linear features. In this area, the dominant NW-trending basement faults show lengthy zones of parallel to subparallel linear features on the surface. There are several areas in Ector County where there are anomalous NE-trending surficial linears that do not correspond to obvious subsurface features. This NE-trending zone, however, has been designated as the Andrews Shear Zones and is thought to represent a primary basement structural boundary. It is marked by a strong negative gravity and magnetic anomaly (see later discussion in potential field geophysics section). In contrast, to the south in Crane, Upton and Pecos counties, there is less correlation with the magnitude of displacement on subsurface faults and the presence of parallel surficial linear trends. The Concho and Pecos regional lineaments mapped by Bolden (1984) do manifest themselves as zones of shorter linear features. These lineaments do appear to separate areas of distinct 
linear feature trends as discussed earlier. In addition, along their trace they are responsible for the local lack of correlation between the subsurface structural trends and the surficial linear features. 


\section{Comparison Between Interpreted Linear Features and Subsurface Structural Trends:}

Ellenburger Structural Datum Fold Axes

(for area $31-33^{\circ} \mathrm{N}, 102-103^{\circ} \mathrm{W}$ )

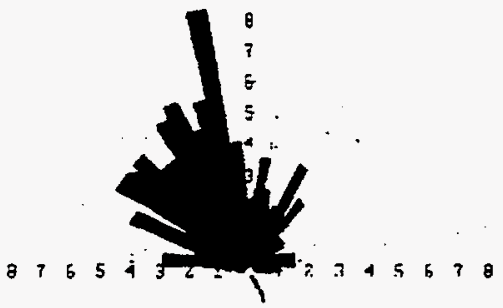

Population

658

Vector Mean.........153.16 degrees

Ellenburger Structural Datum Faults

(for area $31.33^{\circ} \mathrm{N}, 102-103^{\circ} \mathrm{W}$ )

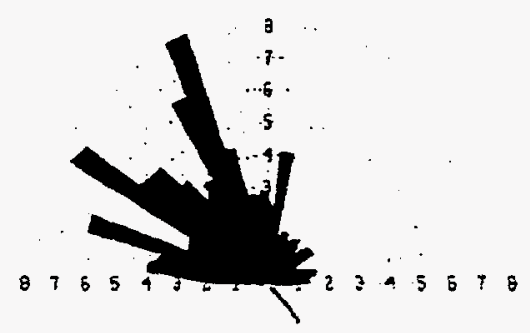

Population 646

Vector Mean. .139 .99 degrees

Mesca Region

(all orientations, unfiltered)

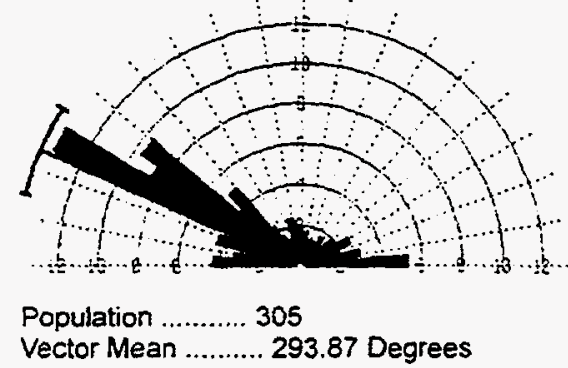

Midland Region

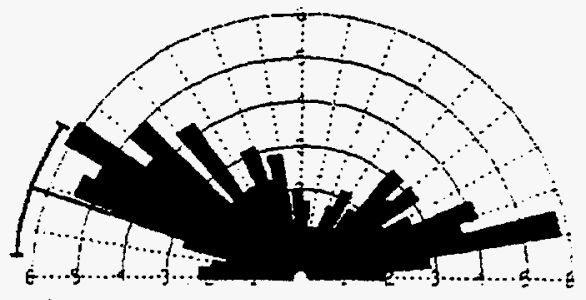

Population

708

Vector Mean

288.56 Degrees

Pecos Region

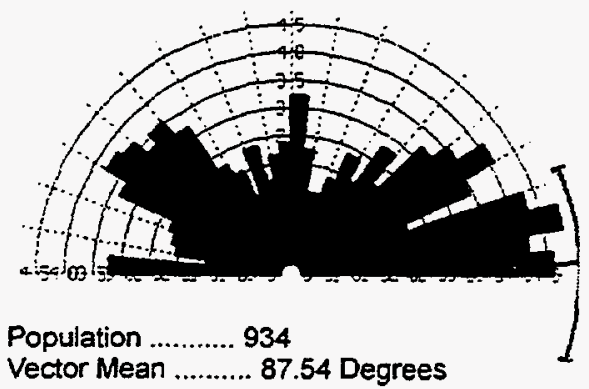

Mesca Region

(filtered data to remove aeolian (?) features possessing trends between $280-310^{\circ}$ )

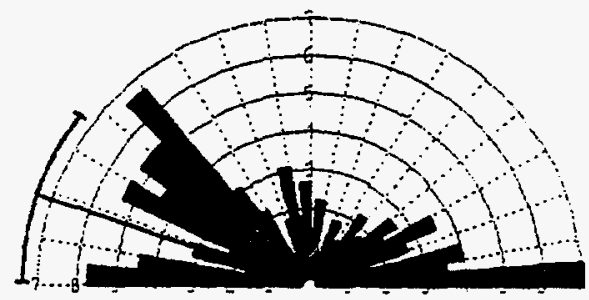

Population ........... 227

Vector Mean

288.52 Degrees

Figure 7: Comparison between subsurface structural trends and surficial linear features. Note similar dominant NW and WNW trends. Also note paucity of NE-trending data in subsurface. 
Given the overall corresponding similarities between surficial linears, subsurface structures and basement structural trends, we are confident that subsurface stratigraphic horizons such as the Clearfork Formation, are fractured along similar trends. As a result, we intend to use those linear features that correlate with deep subsurface structures to constrain fracture trends in shallower Post-Wolfcampian-age subsurface reservoir horizons.

\section{Comparison to maps based on earlier aerial photo interpretation}

In 1969, Phillips Petroleum Company initiated a study of surface linear features using high altitude, stereoscopic aerial photography. The study was limited to Ector County. In comparing the results of this study with the newer LANDSAT imagery interpretation, it is important to remember the much higher resolution of the aerial photos. A\&rial photos have a ground resolution of approximately 1 meter compared to LANDSAT Thematic Mapper which has a 30 meter ground resolution. As a result, aerial photo interpretation will observe smaller features and provide more detail. Unless integrated with other photos from across a region, however, the photo study will often not pick up large features of regional extent. Logistically, it is difficult to work on several dozen (or more) stereopair aerial photos at a single time.

Figure 9 is a composite image of the aerial photographic interpretation with those linears interpreted from LANDSAT imagery analysis. Most of the larger features common to both data sets are apparent. The photo interpretation shows a greater number of additional linear elements, especially along $\mathrm{NW}, \mathrm{E} / \mathrm{W}$, and NE azimuths. Figure 10 compares the linear features interpreted from the aerial photos against those interpreted from the entire Midland LANDSAT image. Although several of the photolinears correspond to subsurface structures, similar to the LANDSAT interpretation, there are numerous surficial linears that do not appear to directly correspond to subsurface structures. Most importantly, the LANDSAT interpretation identified all of the major trends present and was performed much more rapidly. Ground verification of several of the linears may yield additional insight into the characteristics of each linear. However, given the low topographic relief in this area and poor outcrop, it is unlikely that significant information would be gained to make such an exercise fruitful. 

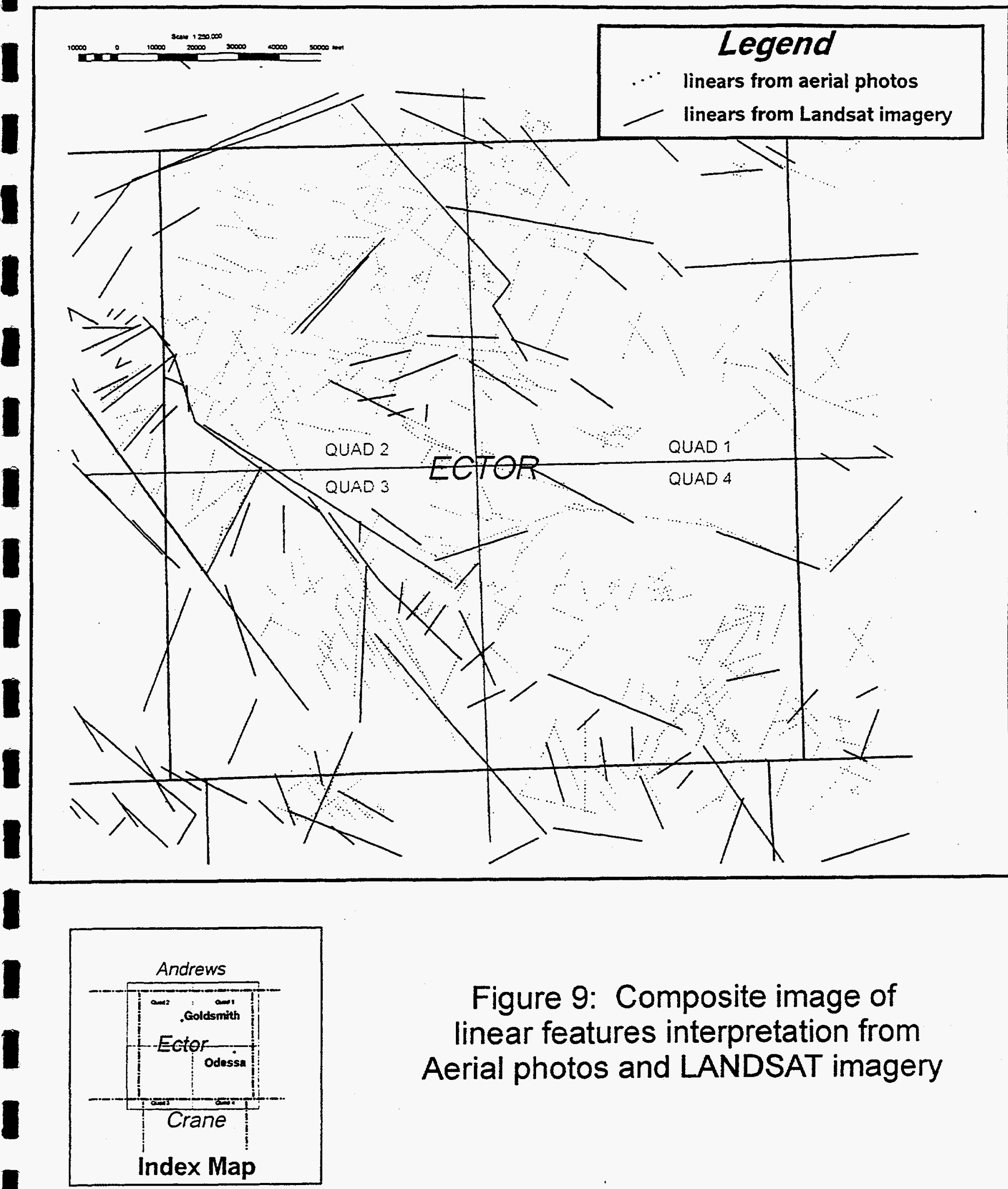

Figure 9: Composite image of linear features interpretation from Aerial photos and LANDSAT imagery 


\section{Interpreted Linear Features: Rose Diagrams}

Ector Photolinears

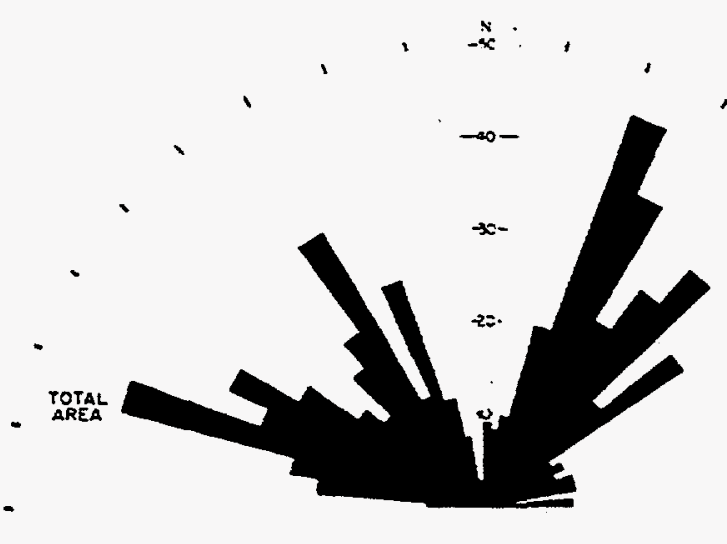

Midland Region-LANDSAT linear

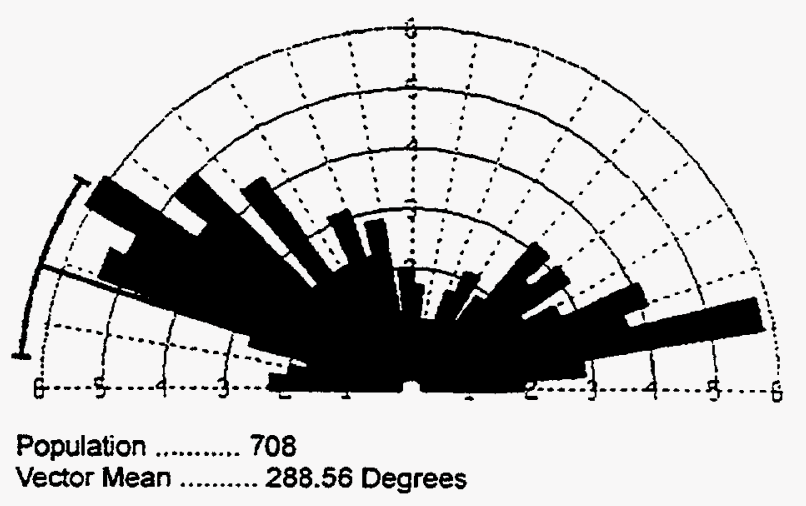

Data from individual four quadrangles on Figure 9.

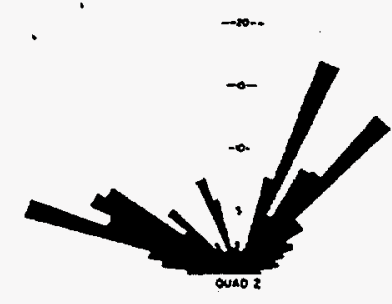

Quad 2

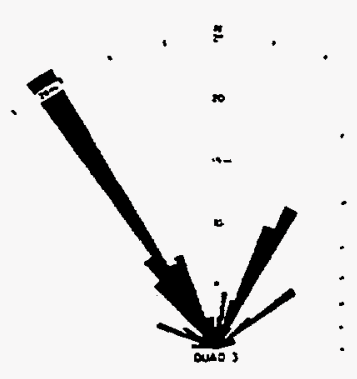

Quad 3
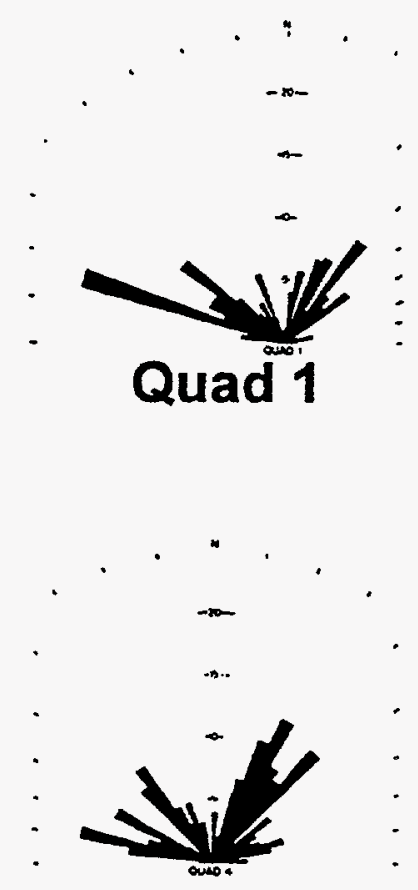

Quad 4

Figure 10: Comparison between aerial photo linear interpretation and LANDSAT linear feature interpretation. 


\section{Aeromagnețics and gravity}

Phillips Petroleum Company provided regional aeromagnetic and Bouguer gravity maps. These maps were supplemented by public domain total field aeromagnetic (NURE) and Bouguer gravity maps (Keller and Peeples, 1985). Phillips' map set contained maps of; total magnetic intensity, total field Bouguer gravity, first and second vertical derivative Bouguer gravity, first horizontal derivative Bouguer gravity, and Bouguer gravity residuals. All of these maps were compared with overlays of published basement block interpretations (Gardiner, 1990; Shumaker, 1992;Yang and Dorobek, 1993; 1995). In general, most of these authors have attempted to subdivide the basement of the Permian Basin into large county-scale ( 40 mile width), fault-bounded basement blocks. When these various block orientations were subjected to crustal stresses related to the Ouachita/Marathon collision to the south, they experienced regional shortening (contractional or thrust faulting) along with wrench deformation (strikeslip motion). The orientation of block boundaries relative to the imposed stress dictates the sense of slip and the partitioning of regional strain between thrust and strike-slip fault displacement. As a result, it is important to compare the various basement geometric models against the potential field geophysical data to give us our best regional perspective (in the absence of seismic mapping of the basement) into the geometry of the basement. Although direct evidence (e.g. wellbores) are considered favorable, additional calibration comes from limited regional seismic interpretation of the basement horizon. By integrating any available basement well penetrations with seismic, we provide the best approach to calibrating our basement structural interpretation. The quality of our basement interpretation is critical because of the widespread interpretation and documentation of basement involvement in thrust tectonics, particularly along and within the Central Basin Platform uplift.

The aeromagnetic map was compiled from NURE (National Uranium Resource Evaluation) program data collected by contractors working for the Department of Energy. This data was that used by Keller and Peeples (1985) and also reprocessed by Phillips Petroleum Company. In West Texas, two different subcontractors collected NURE data using different instrumentation. As a result, re-leveling of the data was necessary that has been performed by several academic groups (e.g. Keller and Peeples, 1985). The aerial surveys were conducted along $E / W$ flight lines at an average spacing of 3 miles. N/S tie lines were flown with a 15 miles spacing. A magnetic measurement or datum was collected approximately every 90-160 feet. Interestingly, Keller and Peeples (1985) have interpreted the magnetic signature of the Central Basement Platform to be of higher amplitude than wauld be expected for such a depth. They believe that the Central Basement Platform is likely cored by mafic rocks that may be related 
to a failed or aborted rift system. Limited penetrations of basement in this area to date, however, have not penetrated such mafic materials.

On the Bouguer gravity maps, the Central Basin Platform is a pronounced gravity high extending to the southeast from West-Central Gaines County to Pecos County. An example of the gravity maps along with the interpretation of Gardiner (1990) is shown in Figure 11. Along its axis, it is broken into two positive anomalies by a NE-trending saddle that extends from the comer of the New Mexico-Texas border into Martin County to the northeast. This zone has been interpreted as the Andrews Shear Zones by Gardiner (1990). He describes this area as a. $15-20 \mathrm{~km}$ wide zone of right-lateral strike-slip deformation. En Echelon folds observed at Enuma, South Andrews, and Midland Farms fields confirm the nature and shear sense. According to Gardiner (1990), the NE-trending swing in the Atokan facies documented in Emma field suggests that the shear zone was active during Pennsylvanian time. Several prominent positive anomalies also correlate with interpreted crustal blocks. Figure 11 is a overlay of interpreted crustal blocks from Gardiner on the total field Bouguer gravity map. Figure 12 is the same interpretation on a aeromagnetic total field map. From these maps, it is possible to delineate most of the crustal block boundaries.

Direct comparison of Gardiner's maps with the data indicate several areas where the interpretation of the potential field data sets could be improved. In general, there are significant differences between the aeromagnetic and Bouguer gravity data sets that favor different interpretations. However, those areas in which the interpretation and potential field geophysical disagree are often directly substantiated by subsurface well control and seismic data. As a result, we have not yet attempted to make a reinterpretation of many of these zones, especially in structurally complex areas, where forthcoming detailed seismic information is required to assess and modify the existing interpretation.

Several authors (Hills, 1984; Shumaker, 1992) have interpreted that the basement decollement or regional detachment surface is found at a depth of approximately 30,0000 feet. As a result, significant basement involvement is interpreted in most structural sections and tectonic reconstructions. Figures 13 and 14 illustrates the interpreted geometry of several basement-involved reservoir structures. Note the overall consistency in interpretation in which the regional thrusts are interpreted to flatten into a regional detachment surface at the $\sim 30,000^{\prime}$ depth. This depth to the regional detachment is supported by the geometry of the fold structures in which the hangingwall ramp would indicate a similar depth to the 


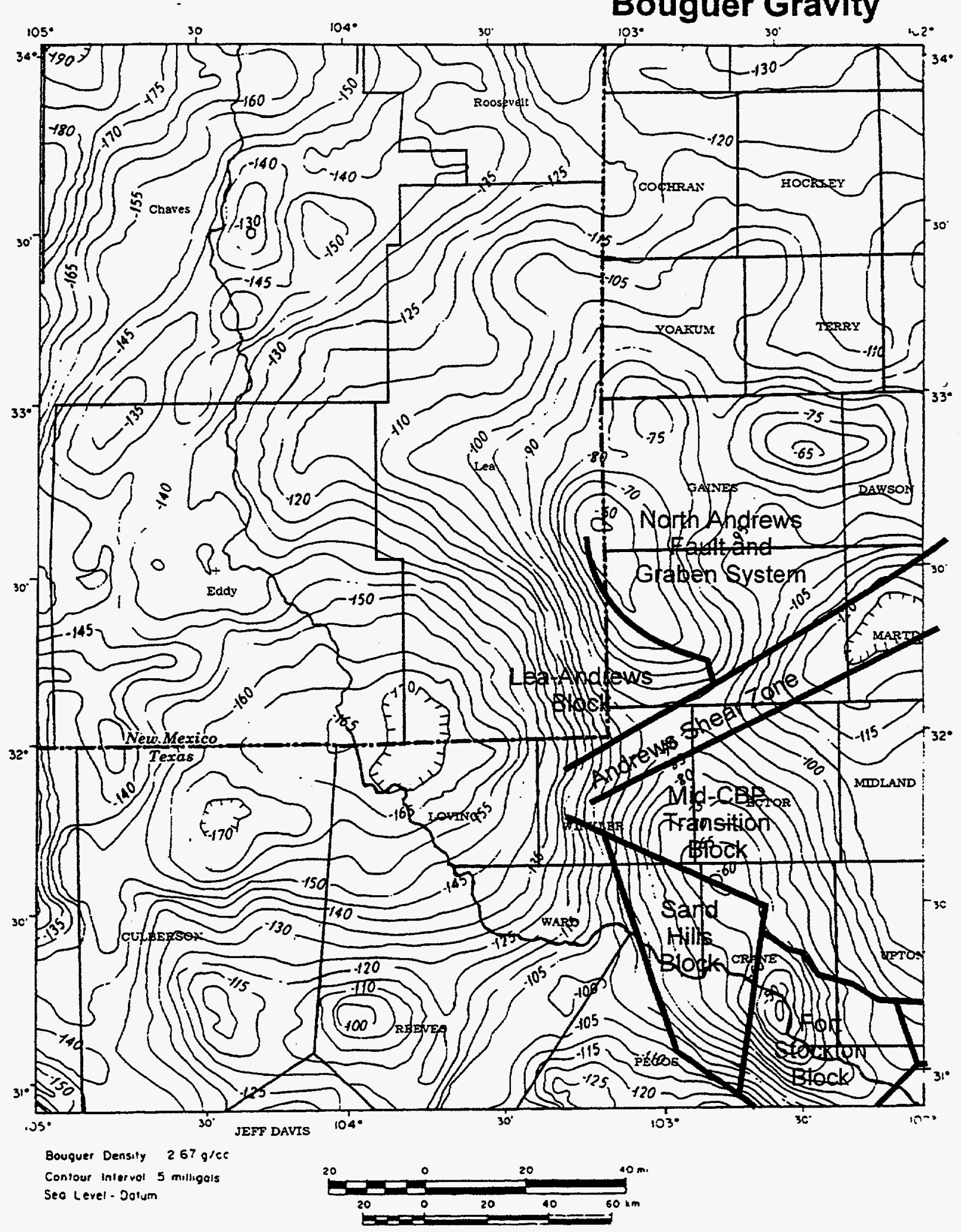

Figure 11: Interpreted crustal blocks from Gardiner (1990) on regional Bouguer Gravity basemap 


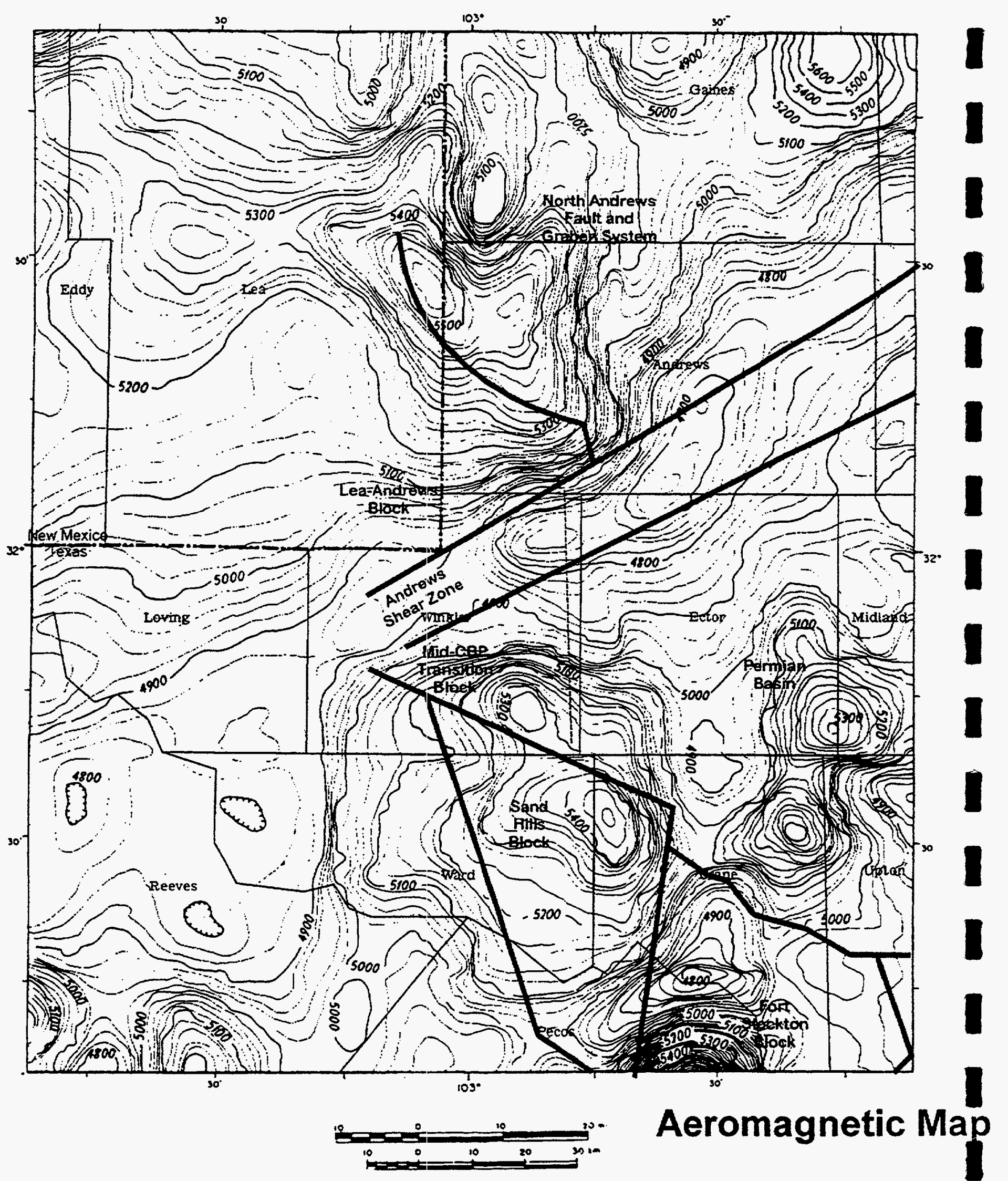

Figure 12: Interpreted crustal blocks from Gardiner (1990) on regional aeromagnetic basemap 

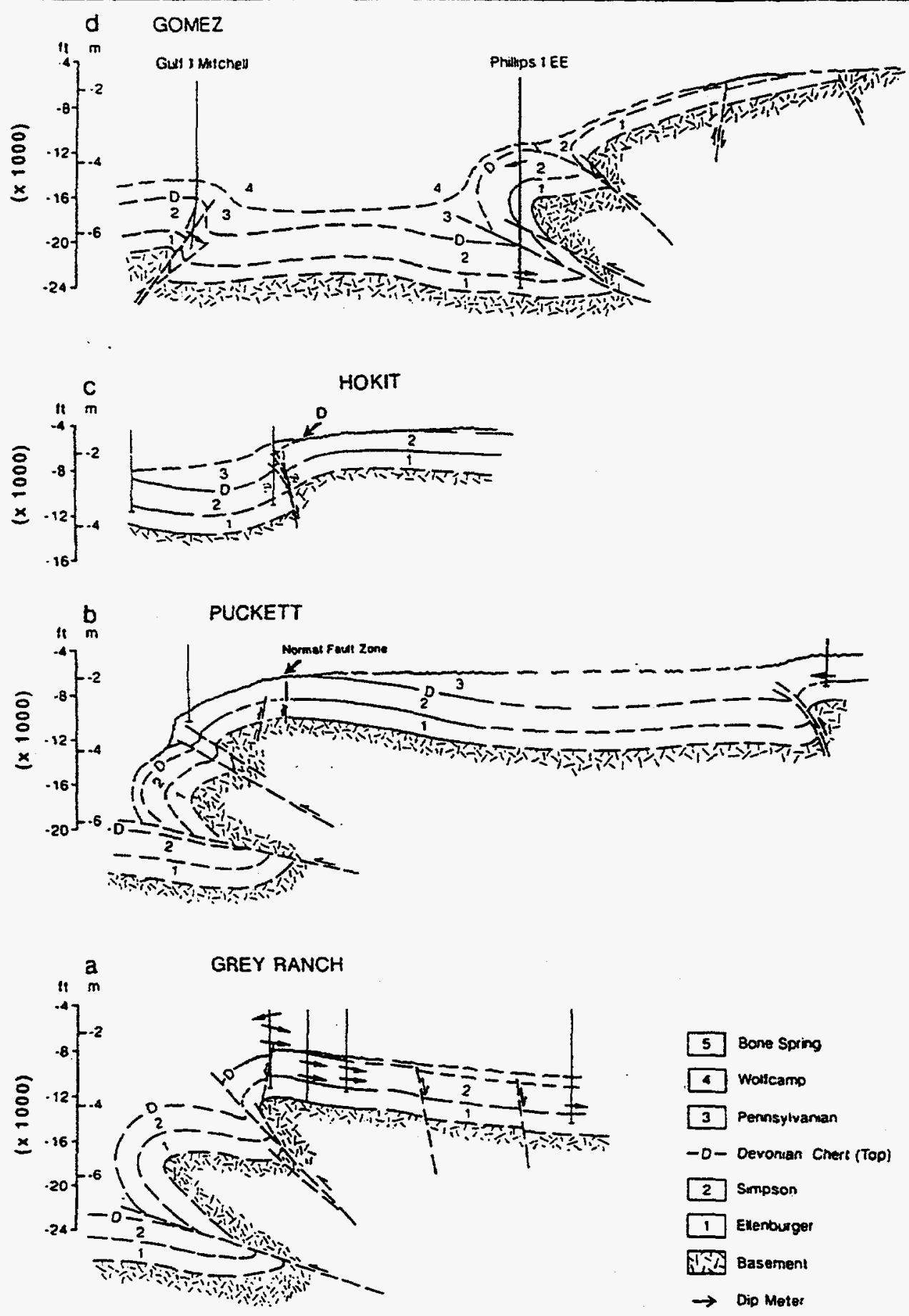

Figure 13: Complex fold and thrust relationships along the Central Basin Platform Margin, Note that regional detachment surface has been interpreted at $\sim 30,000$ feet. 

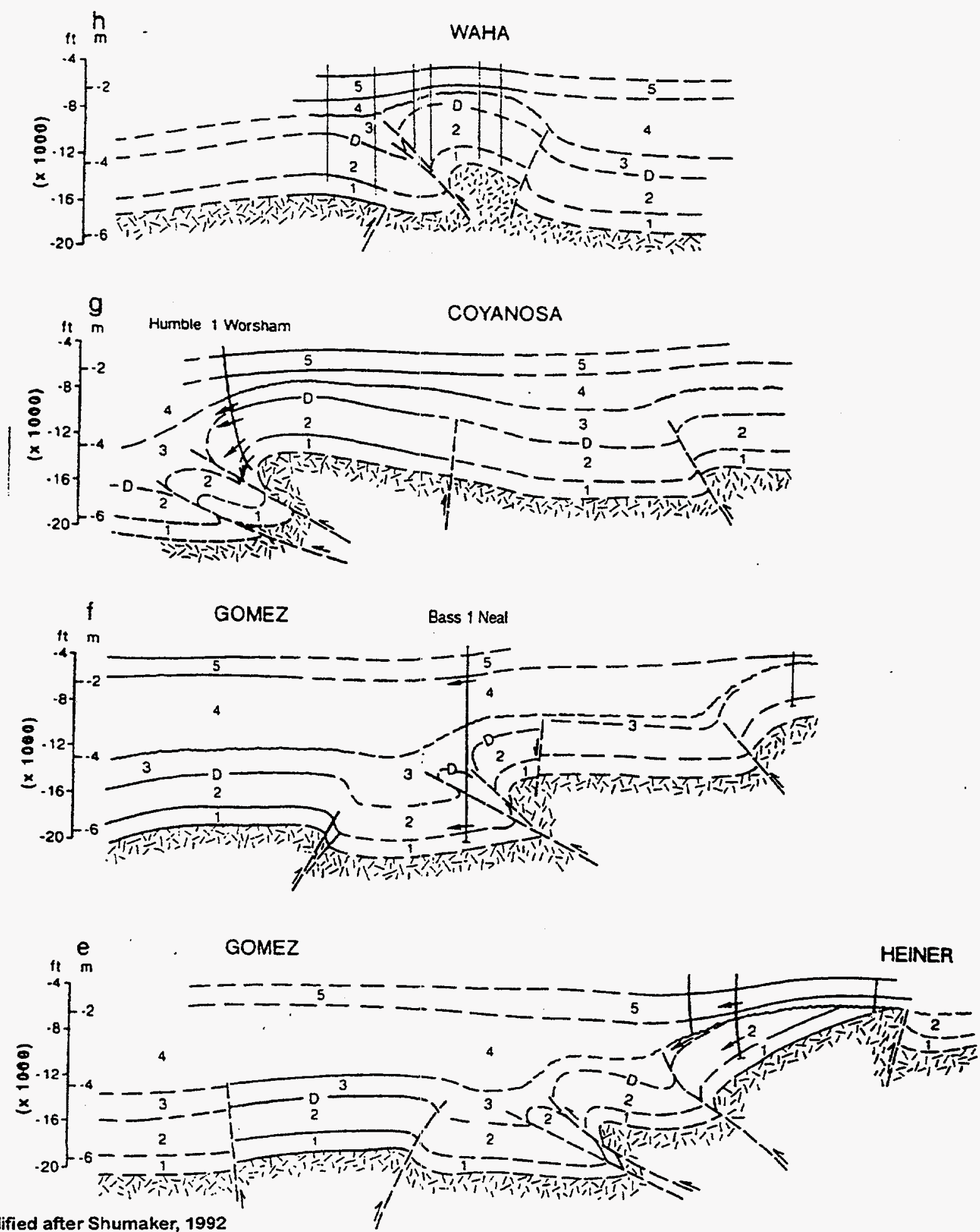

Modified after Shumaker, 1992

Figure 14: Structural sections illustrating complex, basement-involved fold and thrust relationships along the Central Basin Platform Margin. Note relatively low angle dips of fault planes. Majority of regional detachments lie at $\sim 30,000$ feet. 
regional detachment.- Ideally, we could directly compare basement magnetic susceptibility data, collected from actual basement rock samples, with magnetic maps and gravity interpretations to more closely constrain the interpretations. Unfortunately, there are few penetrations of basement in the modeling area. Because the Ordovician-age Ellenburger Formation, a dolomitized limestone, lies unconformably on a relatively flat basement surface, we can use the geometry of the Ellenburger structural datum to approximate that of the underlying basement.

\section{Ellenburger structural geology}

The Ellenburger Formation represents a laterally continuous dolomitized limestone of Ordovician age. In the study area, its thickness extends up to 1500 feet thick. In most of the area of interest, it lies unconformably on a relatively flat basement surface. As a result, we are able to approximate the basement structural configuration by using an Ellenburger structure map. Existing published maps (Gardiner, 1990) were supplemented by maps from Phillips Petroleum Company for Andector Field, and by structural contour maps purchased from Geomap, Inc. of Midland, Texas. Faults, interpreted fold axes and fault displacements were calculated and digitized for this area. These digital files were overlaid with linear features data, basement block interpretations and other structural interpretations. Because of limited regional coverage purchased from Geomap, we supplemented this interpretation with published regional Ellenburger maps of Gardiner (1990). In the area of overlap, we verified the consistency of the two interpretations. Some minor differences in location are thought to be due to the relatively large scale map published by Gardiner and the subsequent inaccuracies involved in increasing the size of the map to correspond to the Geomap data set. Figure 15 is the composite image of the Ellenburger structure map compiled from the Geomap data and that of Gardiner (1990). In this image, the majority of structures trend NW and most folds show associated faults. The general model of these structures is best approximated by that of fault-propagation folds (see Figure 16). In these folds, initial regional shortening is accommodated by folding above a slowly-propagating thrust fault. One of the desirable aspects of this fold mechanism is the overall steady-state growth. In other words, the fold grows as the associated fault follows a gradual (i.e. non-instantaneous) displacement path. This behavior makes it ideally suited for computer modeling using the CIRF.B code. 


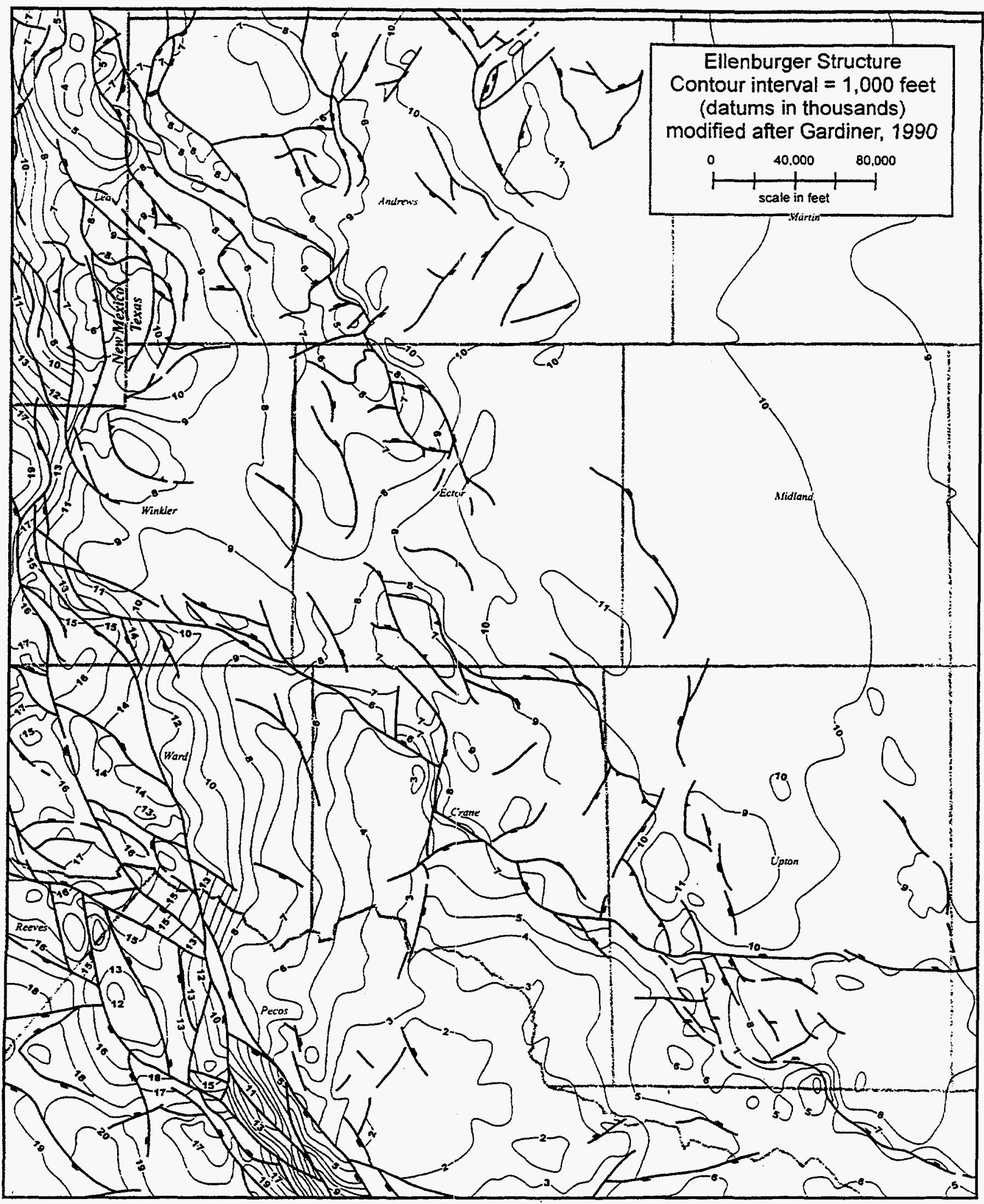

Figure 15: Composite image of Ellenburger structure from Gardiner (1990) and Geomap structure maps 


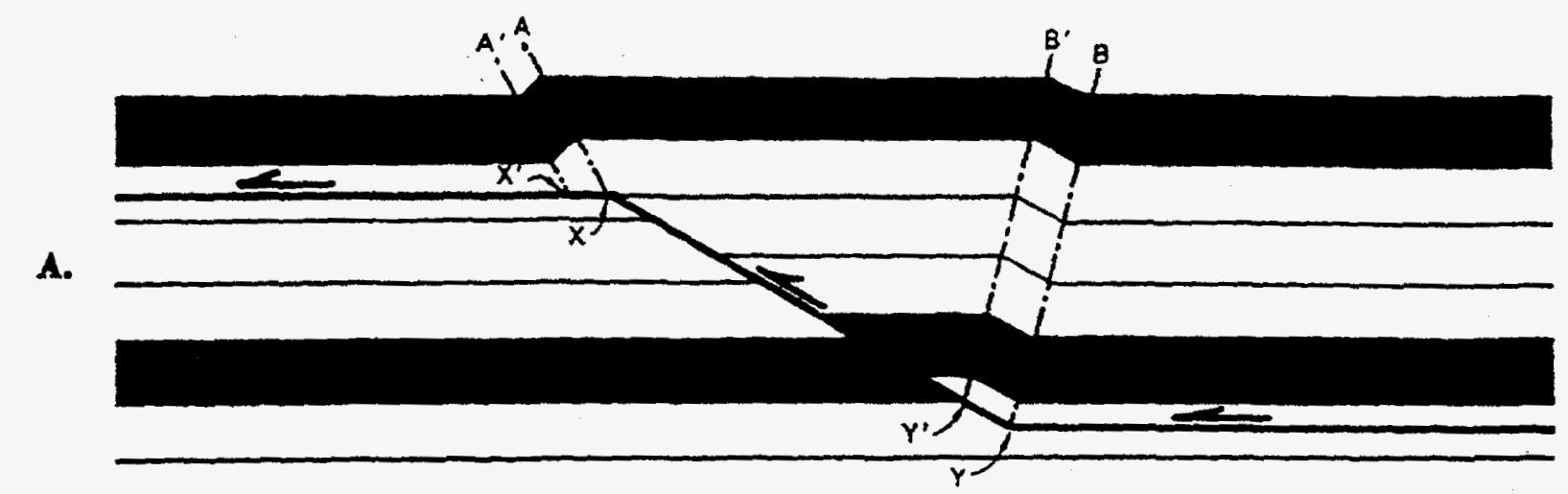

B.
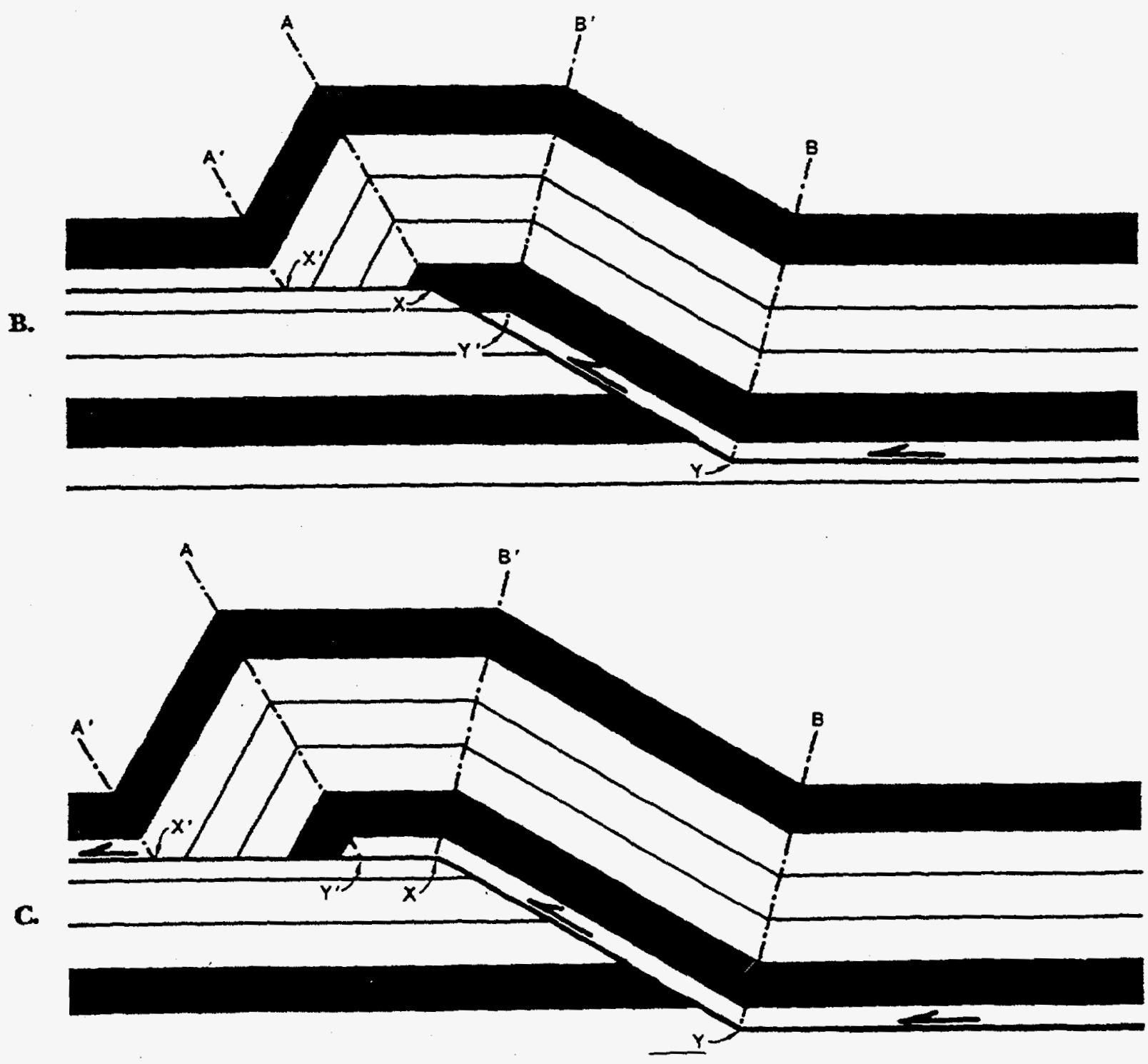

Figure 16. Schematic model of typical fault-bend folds. Note that fold growth occurs simultaneously with incremental slip along fault. Characteristic long limb-short limb relationship is widely observed throughout the Permian Basin. 


\section{Previous studies and existing models}

Integrated tectonic synthesis of the Pernian Basin region has been attempted by only a few individuals. Instead, a much greater emphasis has historically been placed on the complex depositional and diagenetic changes experienced by petroleum reservoir rocks. Because so many major advances in regional interpretation appear to have been driven by technology advances (e.g. additional well control, aeromagnetics, gravity, seismic, etc.), it is particularly informative to study the available literature chronologically.

It has long been recognized that the structural geology of the Permian Basin cannot be fully explained by models involving only pure end-member extensional or contractional (thrust) tectonics. Because of the en echelon fold and fault geometries, combined with complex fault displacement patterns, various amounts of wrench (or strike-slip) deformation have been integrated into regional models. The now-popular model of wrench-dominated regional tectonics is actually quite old. Harrington (1963) was the first geologist to suggest the model of wrench displacement to explain the complex thin-skinned foldand-thrust fault geometries. Harrington recognized two phases of deformation. The first was interpreted to have occurred pre-Atoka time and deformed the 4000-6000' feet of sediments found between the basement and the overlying Barnett Shale. The second phase involved differential subsidence along normal faults that formed after the Wolfcampian-age uplift, synchronous with sedimentation and related loading.

According to Harrington (1963), the first deformation phase, the dominant one in the region, can be geometrically modeled by using wet tissue paper overlying parallel glass plates. By imposing a right lateral shear couple between the glass plates, Harrington was able to demonstrate that the observed preWolfcamp (largely Pennsylvanian in age) fold geometries could be formed by strike-slip motion. In Harrington's model, the dominantly N/S compression imposed by the Ouachita-Marathon thrust system was transferred into $\mathrm{E} / \mathrm{W}$ compression by thin-sikinned deformation along wrench systems. The N/S trending basement fault zones interpreted to flank the Central Basin Platform would have caused local shortening accommodated by folding and thrusting along NW-trends. Perhaps most importantly, especially from an exploration perspective, is Harrington's rebuttal of the long-standing hypothesis that all pre-Permian anticlines must be overlain by a Permian-age or younger structure. The recognition that 
this relationship need not exist was a major stimulus for renewed exploration at deeper structural levels such as the Ellenburger Formation.

Hills (1970) used subsurface data to suggest the possibility of extensive lateral displacement along pre-Permian faults in the Permian Basin. Hills' primary objective was to determine the direction of tectonic forces responsible for regional deformation. Hills interpreted two tectonic systems. The first consists of folds and faults possessing orientations of N35W (folds) and N55-80E (right lateral faults), and N50-65W (left lateral faults). The age of this deformation is thought to be early Late Mississippian to late Middle Pennsylvanian. There also are a series of NNW-trending faults that appear to be right lateral systems with larger displacement that formed synchronous with the other faults. It is this system of conjugate faults that has been interpreted to control the jagged geometry of the Central Basin Platform, especially along its eastern margin.

A second, later deformation phase as interpreted by Hills (1970), is marked by the relaxation of stress and normal fault motion reactivation of older fault systems. The timing of this deformation is interpreted to be middle-to-late Permian in age and fault displacements relatively minor. It is this deformation that apparentiy localized evaporite deposition in the Permian stratigraphy by controlling the geometry of salt pans. Finally, during the Tertiary, the western margin of the Permian Basin was uplifted and Basin-and-Range tectonism commenced in this area. This deformation has apparently been restricted to the western Delaware Basin and the basin margin.

Hills (1970) outlined four pieces of evidence which he felt indicated the dominance of wrench motion: 1) lack of thickening of pre-Permian rocks; 2) analogous distribution of hydrocarbon reservoirs on both sides of several major faults; 3 ) the steepness of the fault planes; and, 4) the ability to explain observed geometries with lateral displacement with only limited reverse sense displacement. Given the apparent conjugate relationships between the NW-and NE-trending fault systems, Hills suggests that the primary regional compression direction was oriented approximately E/W. Over time, the gradual relaxation of the $E / W$ compressive regime was replaced by a more $N / S$ orientation. The timing of folding related to this latter stress regime is dated sometime between late Pennsylvanian to early Permian time.

In a later paper, Hills (1984) discussed the tectonic evolution of the Delaware Basin, especially the thermal and maturation history of the region. Additional information, including a basement 
interpretation based on potential field geophysical data, is presented which suggests that the basement in the region is part of a $\mathrm{N} / \mathrm{S}$ trending aulacogen. Little new information was presented to modify the earlier (1970) interpretation of the structural evolution of the basin. This aulacogen interpretation was modified in a later publication (Hills, 1985).

Hills (1985) summarized the current understanding of the tectonic evolution of the Permian Basin. Although the overall stress regime evolution was not modified, additional significant detail was presented on the tectonic evolution and timing constraints on basin evolution. Most importantly, Hills provides an excellent, though condensed, summary of the geologic evolution of the subdomains or regions that together constitute the Permian Basin. There are several important points that should be discussed in detail. Hills (1985) describes the eastern bourdary of the Midland Basin as possessing little evidence of tectonism. Instead, the Eastern Shelf is largely a stratigraphically-controlled boundary with rocks of the Pennsylvanian-Permian-age carbonate shelf dipping gently westward into the basin. Underlying this shelf, the basement gradually becomes shallower to the east. Hills attributes the observed deformation to a late Precambrian-age event that formed the Paleozoic-age Tobosa Basin and a early late Paleozoic deformation that formed the deep complex fold and thrust structures that dominate the regional structural geology. Tertiary and later tectonic deformation was restricted to the far western margin of the Delaware Basin. Limited Tertiary intrusive activity is found within the Delaware Basin but its influence is considered minor. In addition, Hills demonstrates the dissimilarity in structural intensity found across the Central Basin Platform. The magnitude of faulting is considerably greater along the CBP-Delaware Basin Boundary. This assessment has helped us to refine our modeling area of interest to extend eastward from the top of the CBP. Given the limited tectonic deformation in the Midland Basin, particularly as we move eastward, we can arbitrarily choose the eastward limit of our modeling boundary.

Hills (1985) also describes jointing and minor faulting to be more intense over the edges of deep thrust zones of early Wolfcamp age. This suggests the importance of accurately mapping these zones to delineate zones of enhanced fracture permeability critical to production.

One of the earliest modern integrated models was that of Gardiner (1990). Gardiner performed a study that integrated potential field geophysics, seismic and subsurface interpretation (including erosional limits) to develop a model of regional deformation. The primary objective of the work was to map the regional Paleozoic fault fabric and determine the spacing and evolution of the major fault/fold systems. Gardiner greatly extended the work of Hills and refined the basement block boundaries. From this work. 
Gardiner outlined the boundaries of six "crustal" blocks that are roughly 40 miles on their longest dimension (see Figure 17). The boundaries of these blocks represent major discontinuities that separate zones of distinct or different structural orientations and /or structural styles. In addition, Gardiner established a time sequence of tectonic events for the $\mathrm{CBP}$ and developed a predictive model to recognize undiscovered fault systems.

A map of Ellenburger structure (see Figure 18) demonstrates that the majority of deformation occurs along faults that form the boundaries of Gardiner's crustal blocks. The centers of the blocks are relatively undeformed. Erosional limits are markedly affected by the block boundaries and are used to delineate the chronology of block development and interaction.

The modeling area of interest (especially the Gandu Unit) lies primarily within the Midland Basin, the Mid-CBP transition zone, and the Andrews Shear Zone. As a result of our limited focus, we will only discuss Gardiner's detailed results for these three areas. The Mid-CBP Transition Block is an area of -1600 square miles dominated by NW-trending reverse faults in the northern area (including Gandu Unit) and NW-trending reverse faults in the southern area. Both areas contain less dominant NE-trending normal faults. There is a NE-trending sag corresponding to the center of the area. The majority of traps are faulted anticlines thought to be associated with left lateral strike-slip deformation along the southern block boundary. According to Gardiner, the central blocks were uplifted from Barnett through Atokan time. The eastern edge was uplifted slightly later from Atokan to Strawn time.

The Andrews Shear Zone underlies an area of $\sim 850$ square miles dominated by NE-trending faults and folds within an overall right lateral shear zone. The area is dominated by en echelon folds and possible eroded flower structures. There is some stratigraphic trapping potential associated with the Woodford erosional limit. The area experienced slight movement from the late Mississippian but the majority of motion occurred from the Atokan through late Wolfcampian.

The Midland Basin area is a large area (> $>000$ square miles) that is dominated by small NE and NW-trending faults and related folds. All structures are similar in style but smaller in size to those seen in the Mid-CBP Transition Zone. Principal traps in the Midland Basin include restraining bends along strike-slip faults and small faulted anticlines. Additional production is found in stratigraphic traps, especially pinch-outs and erosional truncations. The majority of uplift occurred prior to the 
Mississippian with isolated fault block movement during Barnett-Strawn time. Since that time, the region has experienced regional subsidence.

As Gardiner concludes, the future production potential of the Permian Basin is slight compared to its history. However, there appears to be additional areas for exploration along the margins of the structural blocks where oblique-slip motion between blocks enhances the development of fractured structural traps. Stratigraphic traps are best pursued within the interior of the blocks where depositional influences can be understood without the complexity of the pervasive tectonic overprint.

Shumaker (1992) expanded on the work of Hills (1985) and provided more detailed documentation of deformation processes, especially in folded-and-thrusted oil fields along the Central. Basin Platform. Shumaker identifies and describes structural styles present in the Central Basin Uplift and adjacent Delaware Basin. These structures are put into a regional framework that integrates the results from numerous published field studies to arrive at an interpretation that minimizes the significance of strike-slip deformation except along several well-documented zones. One of the most interesting results from Shumaker's study is his synthesis of the along-strike variation in fold and thrust geometry along the western margin (eastern edge of Delaware Basin) of the Central Basin Platform. Historically, this boundary had been interpreted as a significant wrench system (e.g. Hills, 1970). Shumaker, however, showed that the thrusts are relatively shallowly-dipping and that there is significant duplication of stratigraphy related to the complex folding and thrusting (see Figure 19). Shumaker does not find the large (tens of miles, Hills, 1970) strike-slip displacement on the West Platform Fault. Instead, it appears that this zone is dominated by reverse faulting and tight folding. In addition, Shumaker finds little evidence for the regional system of N/S-trending right lateral strike-slip faults previously interpreted (Hills, 1970). Instead, according to Shumaker, the region has experienced differential uplift and variable vergence because of an overall left lateral shear imposed along E/W and WNW-trending faults throughout the Central Basin Uplif. Lesser amounts of right lateral slip have occurred along the less important (to accommodate regional strain) NE-antithetic faults. This fault geometry results in an overall counter-clockwise rotation of blocks within the Central Basin Uplift. Variations in fold trends and reverse faults may reflect differential rotation of fault blocks rather than complex changes in regional stress. As a result, it is believed that most of the structures formed within the context of an overall E/Woriented regional principal compressive stress. 


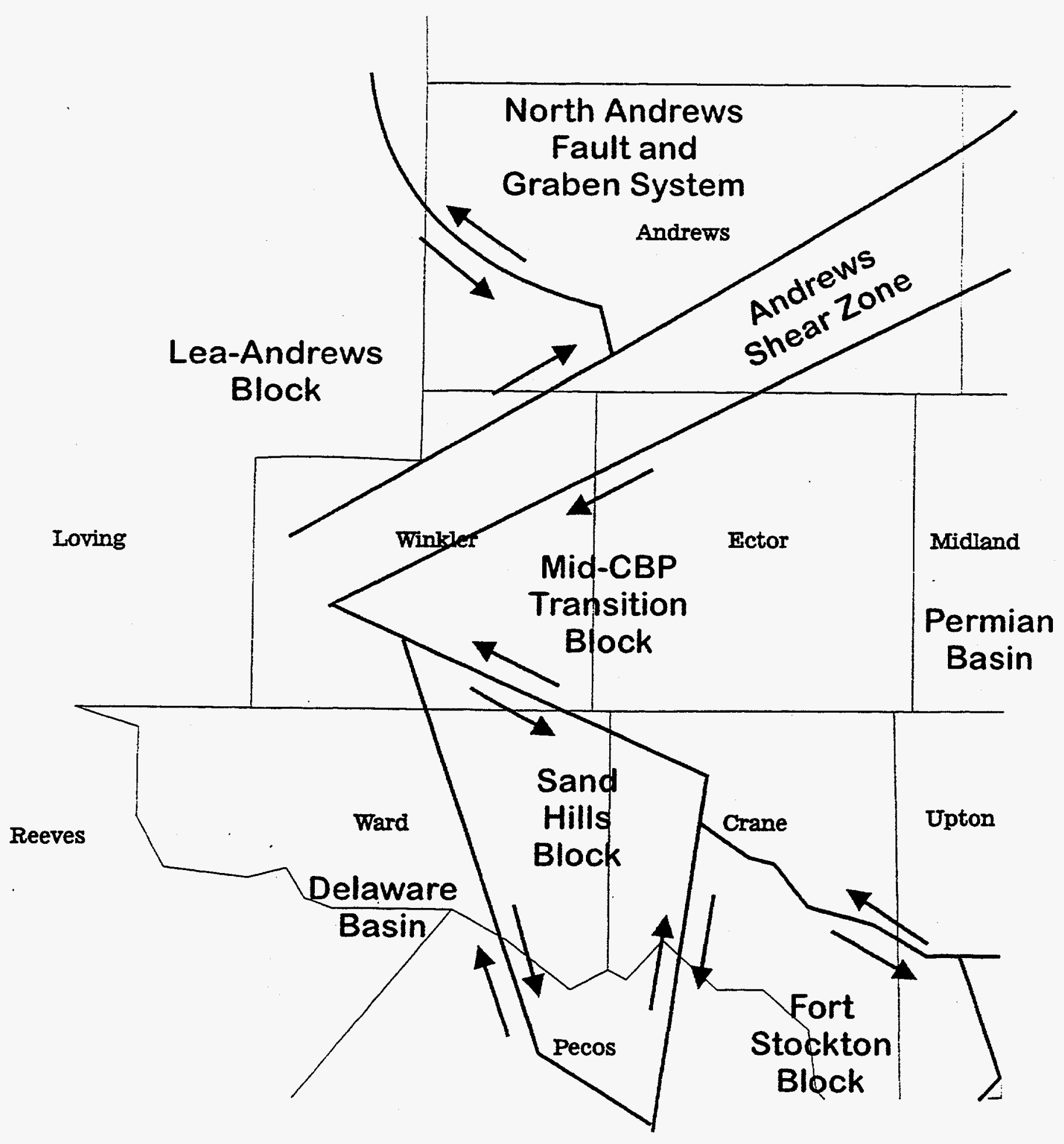

Figure 17: Interpreted crustal blocks from Gardiner (1990). Interpretation based on integrated analysis. 


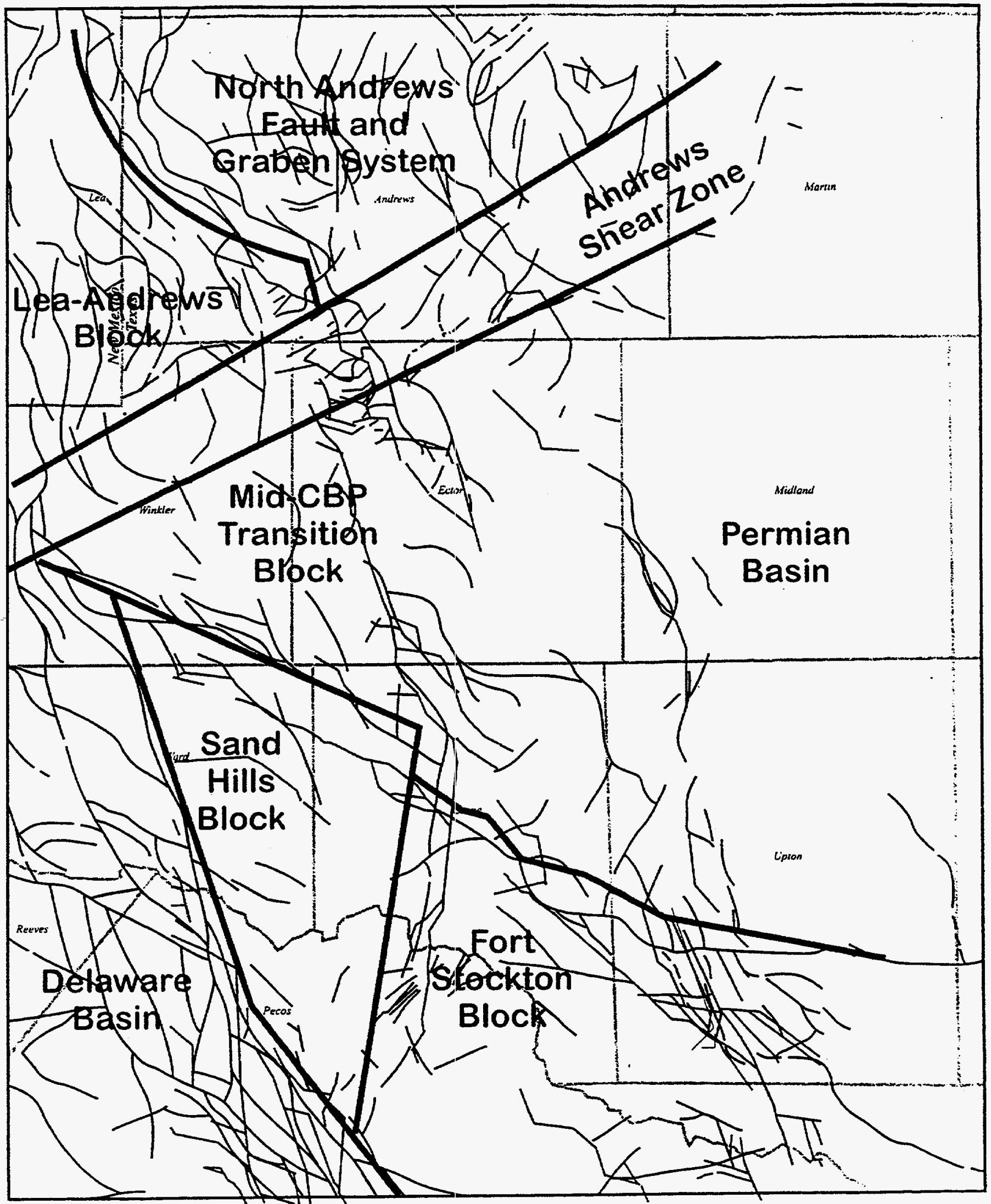

Figure 18: Interpreted crustal blocks from Gardiner (1990) on Ellenburger regional structure basemap 


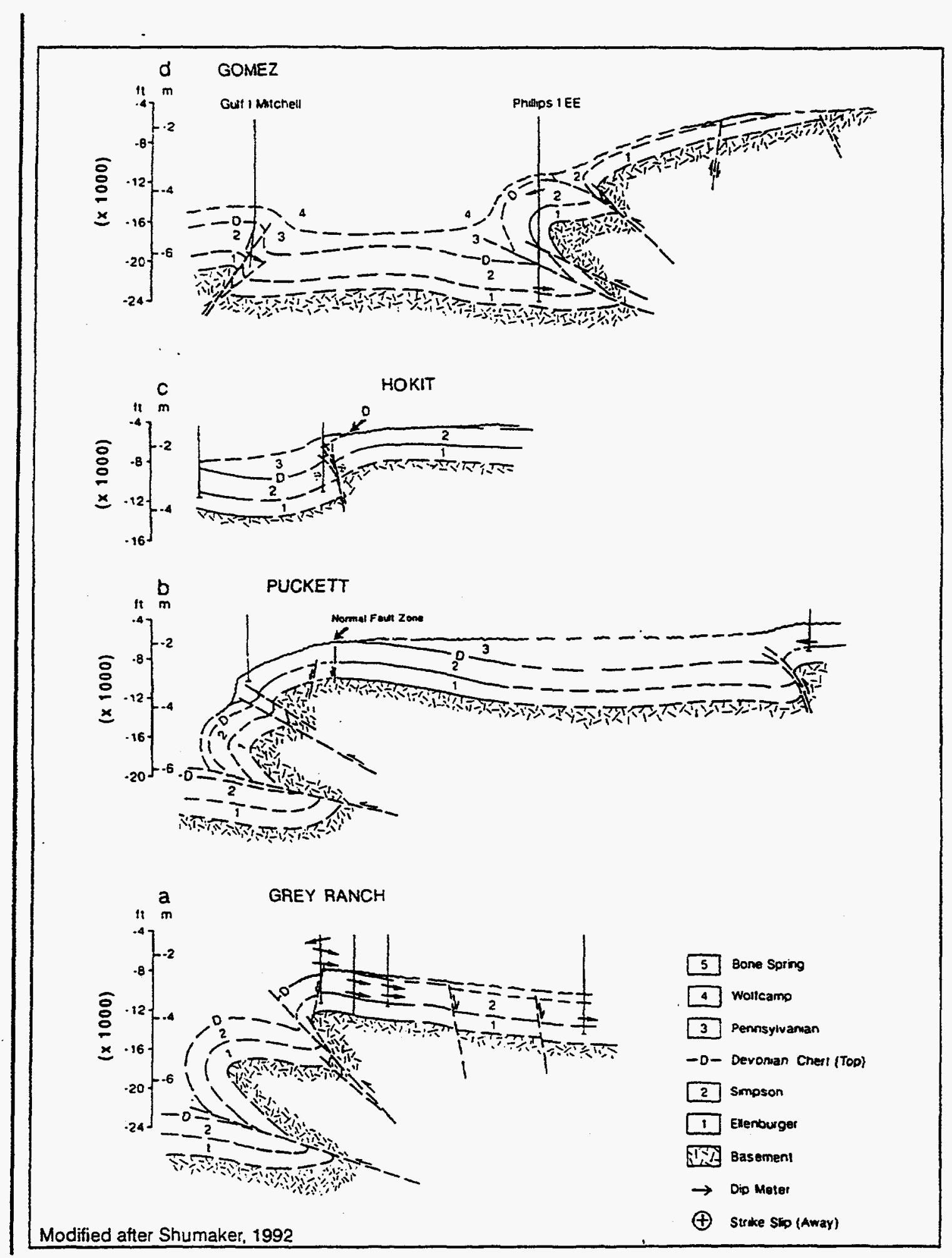

Figure 19A: Structural sections illustrating complex fold and thrust relationships along the Central Basin Platform Margin. Note that regional detachment surface has been interpreted at $\sim 30,000$ feet. 

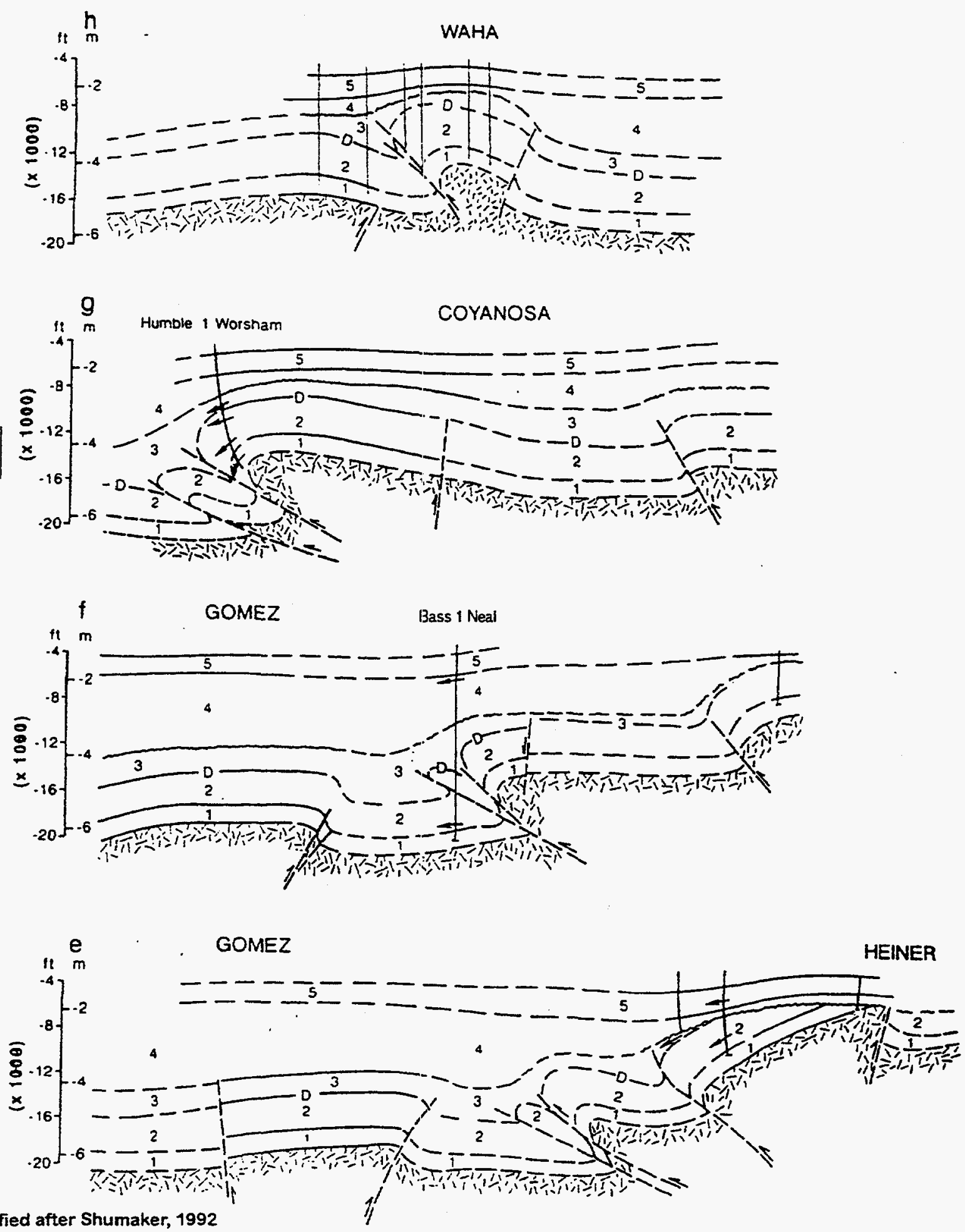

Modified after Shumaker, 1992

Figure 19B: Additional sections illustrating complex fold and thrust relationships along the Central Basin Platform Margin. Note relatively low angle dips of fault planes and tight, basement-involved folding. Majority of regional detachments lie at $\sim 30,000$ feet. 


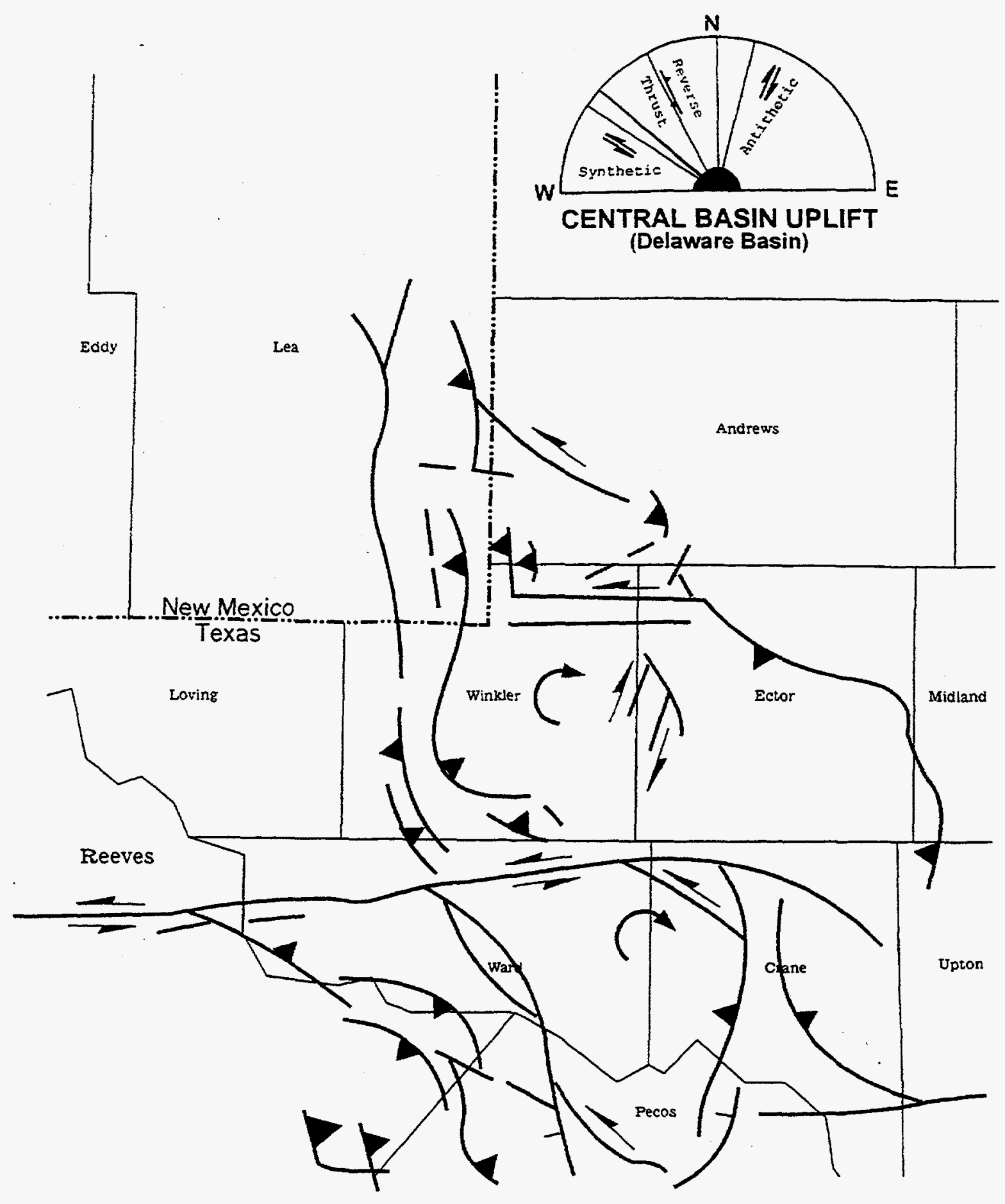

Figure 20: Interpretation of regional kinematics from Shumaker, 1992. Note large numbers of E/W-trending wrench zones.

Overall block rotation is clockwise due to left lateral displacement along NW-trending wrench systems.

Contrast with Gardiner (1990) in Figures 17 \& 18 and Yang and Dorobek (1995) in Figures $21 \& 22$. 
Shumaker's model is confusing because of the relative scarcity (especially on detailed field structure maps) of E/W and WNW faults. These faults are somewhat more prominent, however, on the simplified regional map that Shumaker created. This simplified map (Figure 20) does not show the dominance of NW-trending faults, especially on a field-scale, throughout the region. This simplification incorrectly gives much greater importance to the WNW- and $\mathrm{E} / \mathrm{W}$-trending fault systems. As a result, Shumaker's geometric model is somewhat confusing. By reference to his diagram in the corner of Figure 20, the relationships between structures becomes clearer. The E/W and WNW faults are interpreted as the dominant regional strike-slip faults and show a left-lateral sense of shear. The $N W$-trending faults are dominated by thrusting as is observed in most areas. The NE-trending faults show antithetic shear or right lateral. The overall kinematics of the CB? interior blocks involve counterclockwise rotation. This implies that the displacement along the NE-trending crossfaults is less significant compared to that on the $E / W$ and WNW-trending left lateral set. If the latter NE-trending set (left lateral) did show major displacement, the overall sense of rotation for the enclosed blocks would be clockwise. Because most blocks that compose the CBP, however, do show clockwise rotation (e.g. Gardiner, 1990; Yang ,1993; Yang and Dorobek, 1987; 1993; 1995), however, it is necessary that either the NE-trending crossfaults show greater displacement or an alternative kinematic model is required. The former explanation involving greater displacement along NE-trending faults is contrary to that which is observed.

Interestingly, Gardiner (1990) describes and documents a transition from clockwise block rotation and right lateral shear in the northern part of the CBP that sharply contrasts with the counterclockwise block rotation and left lateral shear in the southern part of the CBP where most of Shumaker's data was based. As a result, the differences between the various models possibly reflect the local geology that typify the different areas in which each geologist performed their syntheses.

A remedy for this significant kinematic problem was defined by Yang (1993) and Yang and Dorobek (1987; 1993; 1995). Yang (1993) and Yang and Dorobek (1987; 1993; 1995) used the earlier work of Gardiner and Shumaker to simplify the geometry of the regional block boundaries in order to facilitate flexure modeling of the CBP and adjacent Delaware and Midland basins. Instead of the six blocks of Gardiner, Yang and Dorobek delineated only two major crustal blocks; the Andector and Fort Stockton blocks. This simplification appears to more closely correspond to the primary differences in structural style between the different areas. Unlike most previous models, Yang and Dorobek had extensive regional seismic data that they used to constrain the geometry of the boundary regions between crustal blocks. They were also able to use these same profiles to better characterize the internal 
deformation within these fault-bounded blocks. As a result, the accuracy of their regional shortening calculation is much better. Most importantly, their model is better able to reflect the deformation observed throughout the region, not just in a limited area where subsurface data are abundant such as in individual oil and gas fields (e.g. Shumaker, 1992).

Yang and Dorobek (1995) generate clockwise rotation of smaller blocks within the CBP by right lateral displacement along NNW-trending fault zones that dominate the CBP. Evidence in support of the model includes: 1) extensive N/S-trending en echelon folds and faults (including flower structures) for the area north of the Andector Block; and 2) close correspondence in structural style between individual E/W-trending faults on either side of the CBP that appear to correlate across zones that have experienced right lateral offset. This model explains the differences in regional shortening observed across the study area (Figure 21). From this Figure, it is clear that there are significant differences in regional shortening along-strike of the Central Basin Platform that suggest a simplified model of regional kinematics (Figure 22). In the model, the non-parallelism of the faults that bound the CBP cause the development of local extension and contraction along the block boundaries. As a result, local transpression and transtension occurs, similar to that documented by Gardiner (1990). Calculated basement shortening decreases northward along the western boundary of the Fort Stockton Block and southward along the eastern block boundary. Similar variations in basement shortening are also observed along the eastern and western boundaries of the Andector Block.

In this study, we will primarily use the results of Yang and Dorobek along with those of Gardiner. This is a logical choice because our primary area of interest lies in the area where these authors had the most data to support their interpretation. In contrast, Shumaker's work concentrated on the CBP southwestern margin where the data indicate a somewhat contrary interpretation. Nonetheless, it seems possible to integrate some of the more general aspects of Shumaker's model.

\section{Regional shortening calculation methodology}

The calculation of regional shortening represents one of the primary objectives of the project and is a critical input into the CIRF.B simulator. To calculate regional shortening, the Ellenburger Formation was used as a structural datum to understand the distribution and displacement history of faults and related folds throughout the modeling domain. From the available Ellenburger structure maps, the vertical displacement was calculated on all faults. In addition, fold axes were interpreted. The majority 


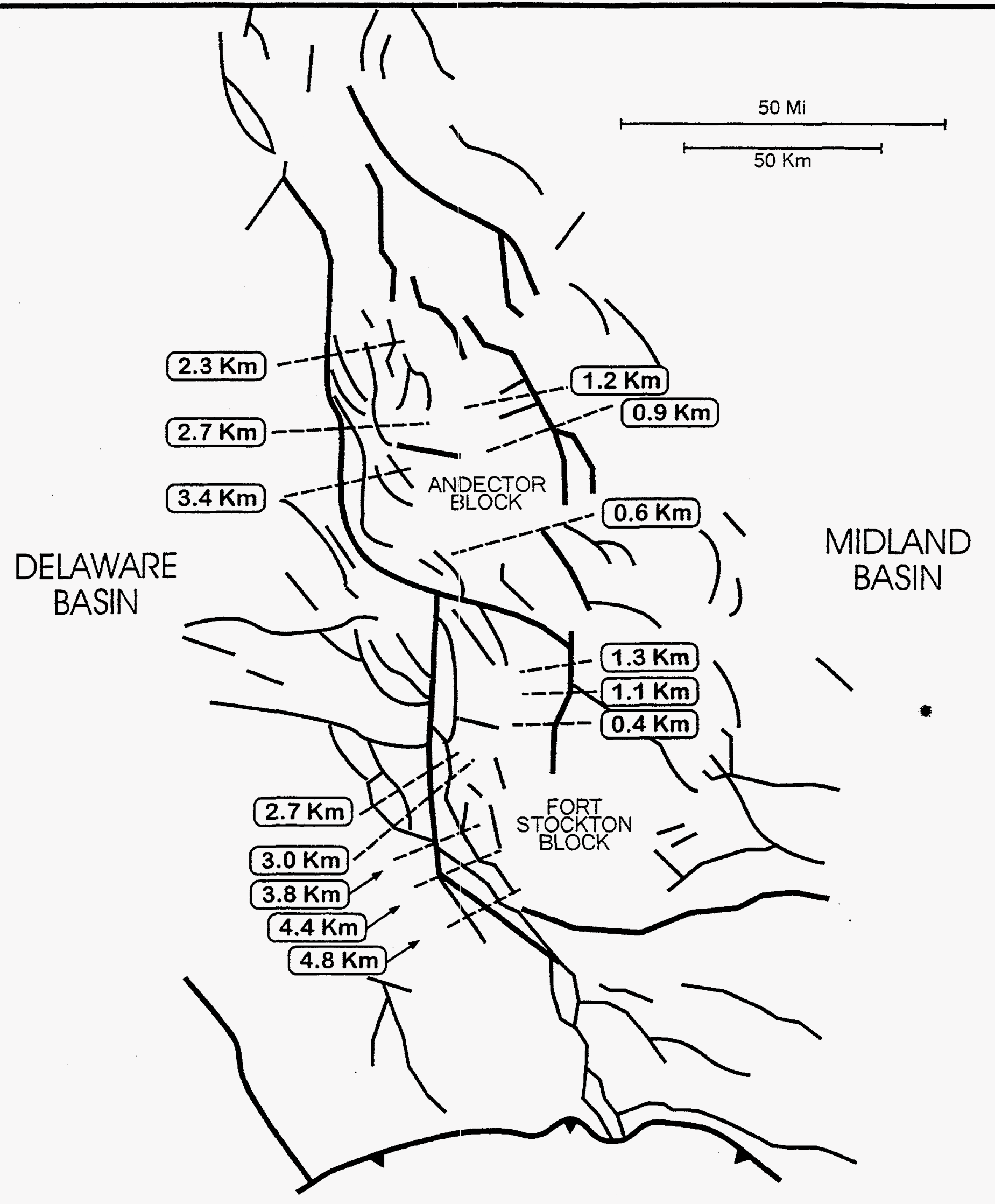

Figure 21: Regional shortening calculations taken from Yang and Dorobek (1995). Note variations in shortening along the different fault zones. 


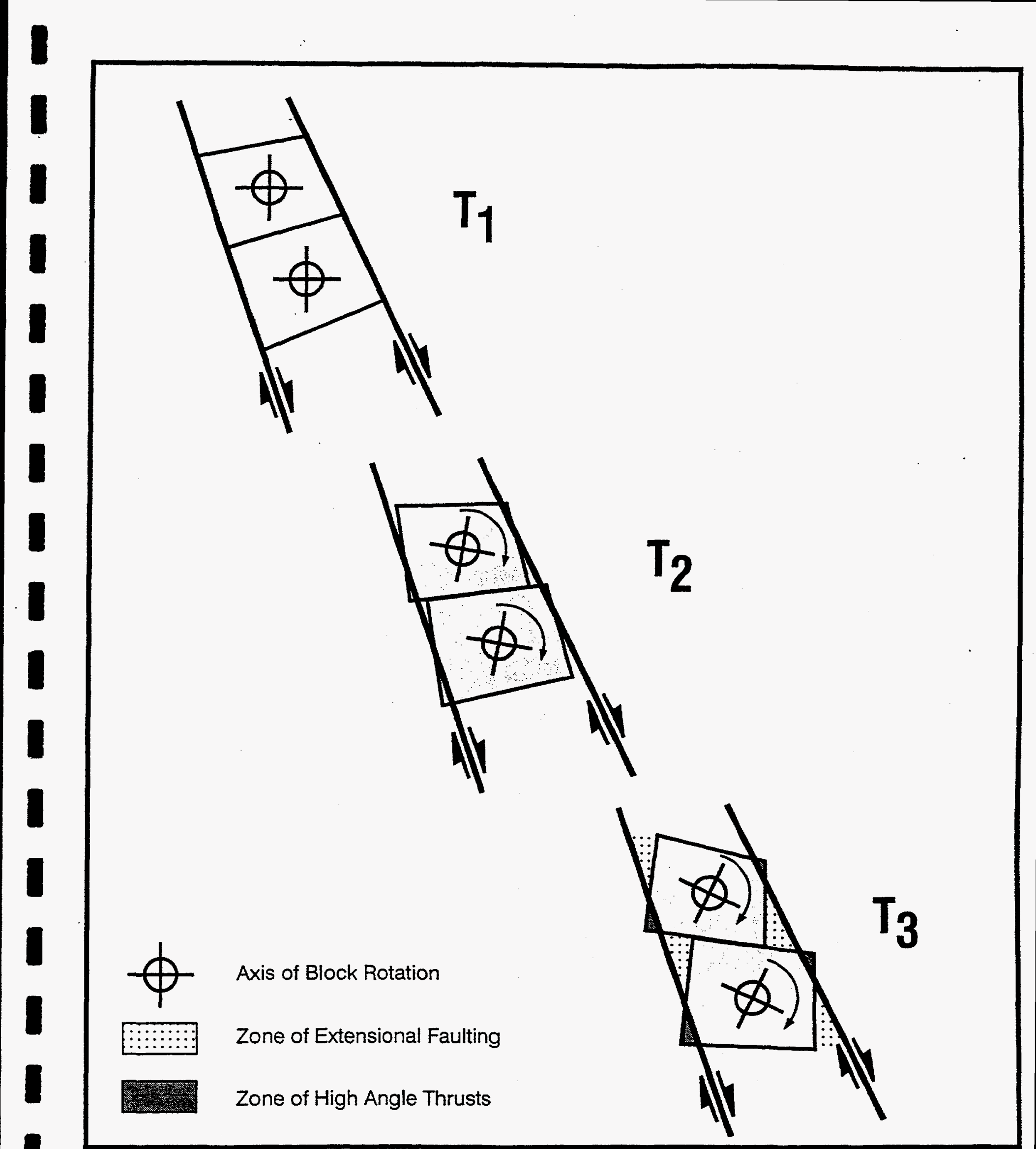

Figure 22. Block rotations proposed by Yang and Dorobek (1995) during the kinematic evolution of the Central Basin Platform. Due to non-parallelism and differential displacement rates along bounding strike-slip faults, significant volume problems are created that require thrusting and normal faulting to maintain constant volume deformation. 
Figure 23: Methodology for calculation of regional shortening on Ellenburger Structural Datum.

Step I:

initial structural configuration
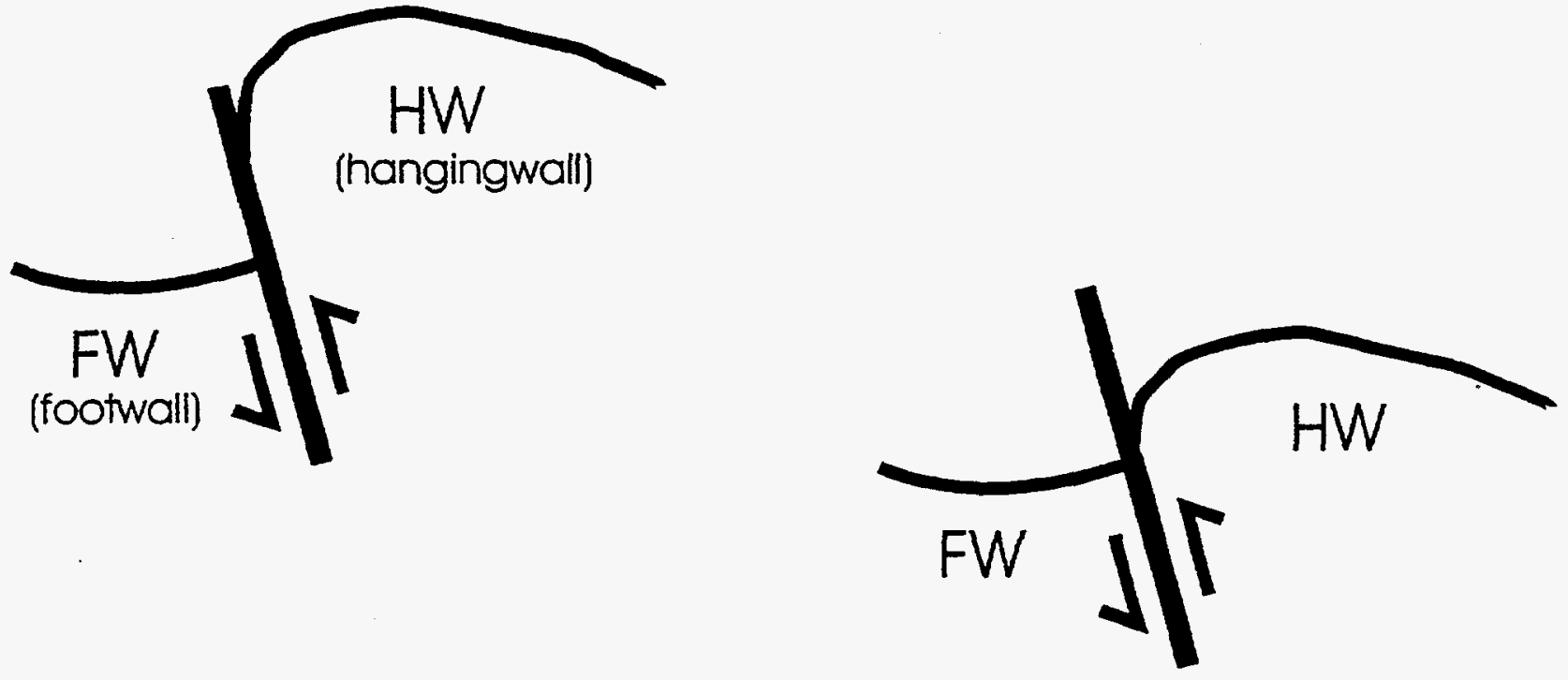

Step 2: Remove fault displacement

by restoring hangingwall/footwall cutoffs.

Calculate shortening due to fault displacem

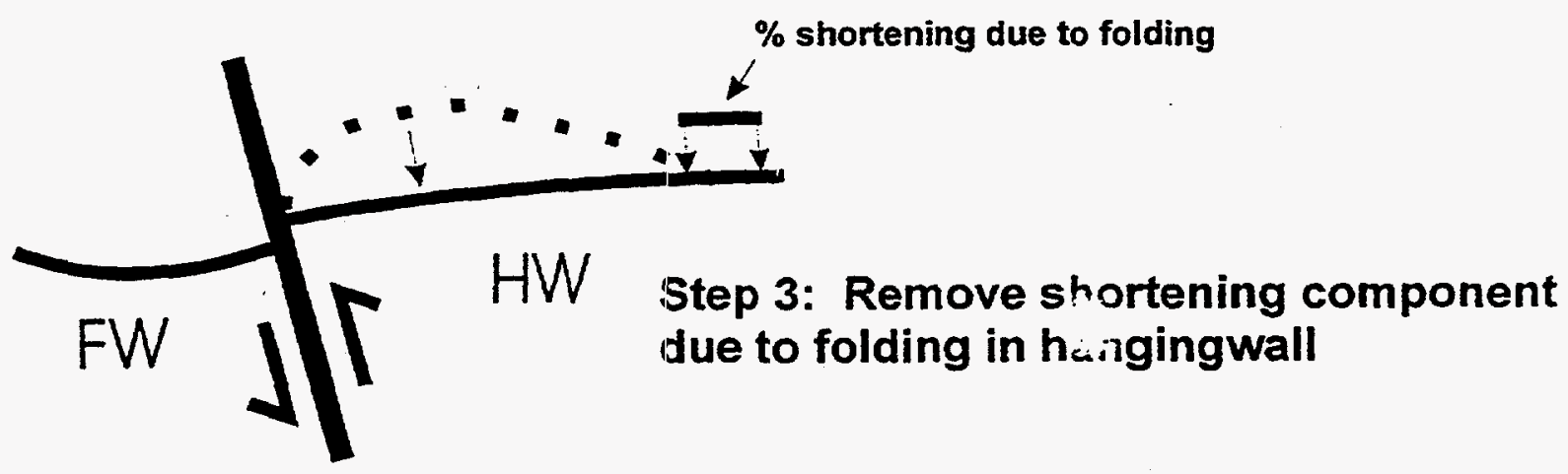


of regional shortening occurred along NE/SW trending section lines. Lesser shortening occurred along an orthogonal direction.

To calculate regional shortening for input into the CIRF.B model, we have used the Ellenburger structural map as a basement-equivalent surface. The methodology for calculating the shortening is two fold. The first step is to remove the displacements on a given fault. The second step is to remove the regional shortening component that was accommodated by folding above this thrust. These two steps are repeated for every fault in the modeling domain. At this point, we have developed the following methodology to generate computer-based grids for CIRF.B input. We have chosen to grid the area of interest with half-mile grid spacing. The orthogonal grid will be laid out parallel and perpendicular to the NE-trending direction of maximum regional shortening. This direction is chosen perpendicular to the maximum fault displacement and perpendicular to the dominant regional fold axes. The second direction is used to calculate the lateral displacement of the grid parallel to the direction of greatest shortening. A schematic of the calculation methodology is shown in Figure 23. Due to previously unrecognized structural complexity in the Andector-Gandu area, it is necessary to have several regional seismic lines to constrain subsurface fault and fold geometries. In the absence of this seismic data, the errors associated with the shortening calculation are potentially serious enough to cause complex three-dimensional strain compatibility and related analytical problems during the modeling. We anticipate having the seismic data available in late January and will discuss and present the regional shortening calculation results in the next quarterly report.

\section{Tectonic development and stress regimes throughout basin evolution}

The evolution of the stress regime over the time frame of basin evolution represents one of the most critical pieces of data for input into the CIRF.B model. By knowing the orientation, duration and magnitude of the far-field regional stresses acting on the boundaries of the modeling regime, we can better predict the geometry and kinematics of crustal movement and fracturing in the model. Local stresses, for example those related to local folding and faulting, will be solved during the CIRF.B model run by the stress solver module.

The majority of authors (Hills; 1970, 1982, 1985; Horak, 1985; Gardiner; 1990; Shumaker, 1992) propose an overall NE/SW-directed regional shortening for the Central Basin Platform and the Midland 
ard Delaware basins. There are several different time frames that have been outlined for the initiation and c.ssation of tectonism in the region.

According to Gardiner (1990), the driving force for deformation in the CBP and adjacent Delaware and Midland basins was the onset of Ouachita deformation in early Mississippian time. This NW-directed Ouachita crustal shortening caused the breakup of basement crust in the CBP into the six major structural blocks outlined earlier. In the CBP area, there are three main episodes of tectonic movement: 1) Barnett time (late Mississippian); 2) Atokan (early Pennsylvanian); and 3) Strawn (midPennsylvanian). In Barnett time, existing NW-trending fault systems were reactivated, marking the initial uplift of the Ft. Stockton, Sand Hills and Lea-Andrews blocks. Regional thickness changes in the Bamett Shale suggest uplift of the CBP began at its center and progressed to the margins. Initial tectonic movement was thought to be vertical prior to increasing oblique-slip during the subsequent phases. During the Atokan, contraction reached its climax, forming throughgoing basement wrench faults. Major systems include the Big Lake-Barnhart fault that; separates the Midland Basin from the Reagan Uplift to the south. This orientation shift is also supported by the Montoya erosion pattern and a magnetic anomaly. In Strawn time, NE-trending faults appear to become active and crosscut the older NWtrending set. Increased wrench motion along the: Andrews Shear Zone probably enhanced the formation of the Inez field anticlinal structure as well as NE-trending faults such as those that form Hutex and Pritchard fields in Andrews County. Continued motion along the NE-trending scissors fault lying between the Ft. Stockton and Sand Hills blocks probably caused a NE-trending regional principal stress orientation. Gardiner has also delineated the dominant structural fabric, trap types and age of structural movement for each of the six structural megablocks. These have been summarized in Table 1 (modified from Gardiner, 1990).

Although Gardiner's synthesis for the regional stress evolution is in general agreement with earlier work (e.g. Hills, 1970; 1982; Font, 1985; Horak; 1985; Price and Henry, 1985) his interpretation is not without controversy. The controversy results from the fact that the NW-trending stress regime from the Marathon-Ouachita collision is oriented at right angles to that interpreted from the NE-trending stress regime interpreted from local fault and fold structures that compose the CBP, Midland and Delaware basins. Horak (1985) discusses the fact that the two stress regimes appear contradictory. He suggests that the Delaware and Midland basins may represent impactogens similar to those observed today in China in front of the Himalaya Thrust Front. Because the Delaware Basin overlies the ancestral Tobosa 
Basin center, it likely represents an area of thickened crust that may have been weaker than adjacent basement areas that underlie the Midland Basin and Central Basin Platform.

An alternative interpretation for thickened crust in the Delaware Basin is based on the potential field geophysics which indicate that the $C B P$ is an area probably underlain by a large mafic mass. The CBP correlated with a gravity and magnetic high or positive anomaly. However, the gravity high is much larger than would be expected based on structural relief alone. This suggests either a mafic core or a thickened crust beneath this area. Given its greater thickness, it may have been older, cooler and more susceptible to uplift during regional shortening.

As Yang and Dorobek (Yang, 1993 and Yang and Dorobek, 1987; 1993; 1995) have shown, the geometry of the Delaware and Midland basins can be satisfactorily modeled as resulting from the flexural response to the imposed load created by the CBP uplift. Following the initial uplift of the CBP, the N/Sto NW-oriented regional stress of the Marathon-Ouachita collision regional shortening was imposed on the dominant NW-trending basement structural anisotropy of the Central Basin Platform. Depending on the kinematics of the local blocks, the regional strain was accommodated by differential shortening (expressed via folding and thrusting involving basement) and strike-slip motion along favorably oriented fault systems. Given the basement involvement, it seems likely that significant shortening was accommodated by the sedimentary cover by shortening and thrusting before throughgoing wrench systems developed in the sedimentary cover. It is this complex juxtaposition and overprinting of contractional and wrench tectonics that has challenged regional interpretations and tectonic syntheses in West Texas and the Permian Basin. 


\section{SELECTED REFERENCES:}

Barnes, V.E., 1983, Geologic Atlas of Texas, Van Hom-El Paso Sheet, Bureau of Economic Geology, The University of Texas at Austin.

Barnes, V.E., 1983, Geologic Atlas of Texas, Elig Spring Sheet, Bureau of Economic Geology, The University of Texas at Austin.

Bolden, G.P., 1984, Wrench Faulting in Selected Areas of the Permian Basin, in: Moore, G. and Wilde, G., eds., Transactions of the Southwest Section of the AAPG, Southwest Section Publication 84-78, 131-140.

Borger, R.L., 1990, An Example of the Use of Satellite Image Analysis and Digital Data Integration in Exploration for Hydrocarbons in West Texas, in: Flis, J.E. and Price, R.C., eds., Permian Basin Oil and Gas Fields: Innovative Ideas in Exploration and Development, Midland, Texas, West Texas Geological Society Publication 90-87, 1-11.

Ewing, T.E., 1990, The Tectonic Map of Texas, Bureau of Economic Geology, Austin, Texas The University of Texas at Austin.

Ewing, T.E., 1990, The Tectonic Framework of Texas: Text to accompany "The Tectonic Map of Texas", Bureau of Economic Geology, Austin, Texas The University of Texas at Austin. 36 p.

Frenzel, H.N., Bloomer, R.R., Cline, R.B., Cys, J.M., Galley, J.E., Gisbon, W.R., Hills, J.M., Seager, W.R., Kottlowski, R.E., Thompson III, S.J., Luff, G.C., Pearson, B.T., and Van Siclen, D.C., 1988, The Permian Basin Region, in: L.L. Sloss, ed., Sedimentary Cover of North America, Geological Society of America, The Geology of North America, V D-2, 261-306.

Gardiner, W.B., 1990, Fault Fabric and Structural Subprovinces of the Central Basin Platform: A Model for Strike-slip Movement, in: Flis, J.E. and Price, R.C., eds., Permian Basin Oil and Gas Fields: Innovative Ideas in Exploration and Development, Midland, Texas, West Texas Geological Society Publication 90-87, 15-27.

Harrington, J.W., 1963, Opinion of Structural Mlechanics of Central Basin Platform Area, West Texas, AAPG Bulletin, 47, 2023-2038.

Henry, C.A. and Price, J.G., 1985, Summary of the Tectonic Development of Trans-Pecos Texas, Bureau of Economic Geology, Misc. Map \#36, University of Texas at Austin.

Hill, C.A., 1996, Geology of the Delaware Basin Guadalupe, Apache and Glass Mountains New Mexico and West Texas, SEPM Permian Basin Section Publication 96-39, 480 p.

Hills, J.M., 1970, Late Paleozoic Structural Directions in Southern Permian Basin, West Texas and Southeastern New Mexico, AAPG Bulletin, 54, 1809-182.7. 
Hills, J.M., 1984, Sedimentation, Tectonism, and Hydrocarbon Generation in Delaware Basin, West Texas and Southeastern New Mexico, AAPG Bulletin, 68, 250-267.

Hills, J.M., 1985, Structural Evolution of the Permian Basin of West Texas and New Mexico, in: Dickerson, P.W., and Muehlberger, W.M., eds., Structure and Tectonics of Trans-Pecos Texas, Midland, Texas, West Texas Geological Society Publication 85-81, 89-99.

Horak, R.L., 1985, Trans-Pecos Tectonism and its Effect on the Permian Basin, , in: Dickerson, P.W., and Muehlberger, W.M., eds., Structure and Tectonics of Trans-Pecos Texas, Midland, Texas, West Texas Geological Society Publication 85-81, 81-87.

Keller, G.R., and Peeples, W.J., 1985, Regional Gravity and Aeromagnetic Anomalies, in: Dickerson, P.W., and Muehlberger, W.M., eds., Structure and Tectonics of Trans-Pecos Texas, Midland, Texas, West Texas Geological Society Publication 85-81, 101-105.

Shumaker, R. C., 1992, Paleozoic Structure of the Central Basin Uplift and Adjacent Delaware Basin, West Texas, AAPG Bulletin, 76, 1804-1824.

Yang, K-M., 1993, Late Paleozoic Synorogenic Stratigraphy, Tectonic Evolution, and Flexural Modeling of the Permian Basin, West Texas and New Mexico, Unpublished Ph.D. dissertation, Texas A\&M University, College Station, Texas $142 \mathrm{p}$.

Yang, K-M., and Dorobek, S.L., 1992, Mechanisms for Late Paleozoic Synorogenic Subsidence of the Midland and Delaware Basins, Permian Basin, Texas and New Mexico, in Mruk, D., and Curran, B., eds., Permian Basin Exploration and Production Strategies-Applications of Sequence Stratigraphic and Reservoir Characterization Concepts, Midland, Texas, West Texas Geological Society Fall Symposium, 45-60.

Yang, K-M., and Dorobek, S.L., 1993, Late Paleozoic Synorogenic Stratigraphy and Tectonic Evolution of the Permian Basin, West Texas and New Mexico, in: Cromwell, D., and Gibbs, J., eds., New Dimensions in the Permian Basin: 3D and Environmental Geosciences, Midland, Texas, West Texas Geological Society Publication 93-93, 8-18.

Yang, K-M., and Dorobek, S.L., 1995, The Permian Basin of West Texas and New Mexico: Tectonic History of a "Composite" Foreland Basin and its Effects on Stratigraphic Development, in: Stratigraphic Evolution of Foreland Basins, SEPM Special Publication \#52, 149-174.

Yang, K-M., and Dorobek, S.L., 1995, The Permian Basin of West Texas and New Mexico: Flexural Modeling and Evidence for Lithospheric Heterogeneity Across the Marathon Foreland, in: Stratigraphic Evolution of Foreland Basins, SEPM Special Publication \#52, 38-49. 